\title{
Dysregulation of Presynaptic Calcium and Synaptic Plasticity in a Mouse Model of 22q11 Deletion Syndrome
}

\author{
Laurie R. Earls, ${ }^{1 \star}$ Ildar T. Bayazitov, ${ }^{1 \star}$ Robert G. Fricke, ${ }^{1 \star}$ Raymond B. Berry, ${ }^{1,2}$ Elizabeth Illingworth, ${ }^{3,4}$ \\ Guy Mittleman, ${ }^{2}$ and Stanislav S. Zakharenko ${ }^{1}$ \\ ${ }^{1}$ Department of Developmental Neurobiology, St. Jude Children's Research Hospital, Memphis, Tennessee 38105, 2Department of Psychology, University of \\ Memphis, Memphis, Tennessee 38152, ${ }^{3}$ Dulbecco Telethon Institute, 80131 Naples, Italy, and ${ }^{4}$ Università degli Studi di Salerno, 84084 Fisciano, Italy
}

The 22q11 deletion syndrome (22q11DS) is characterized by cognitive decline and increased risk of psychiatric disorders, mainly schizophrenia. The molecular mechanisms of neuronal dysfunction in cognitive symptoms of 22q11DS are poorly understood. Here, we report that a mouse model of 22q11DS, the $D f(16) 1 /+$ mouse, exhibits substantially enhanced short- and long-term synaptic plasticity at hippocampal CA3-CA1 synapses, which coincides with deficits in hippocampus-dependent spatial memory. These changes are evident in mature but not young animals. Electrophysiological, two-photon imaging and glutamate uncaging, and electron microscopic assays in acute brain slices showed that enhanced neurotransmitter release but not altered postsynaptic function or structure caused these changes. Enhanced neurotransmitter release in $D f(16) 1 /+$ mice coincided with altered calcium kinetics in CA3 presynaptic terminals and upregulated sarco(endo)plasmic reticulum calcium-ATPase type 2 (SERCA2). SERCA inhibitors rescued synaptic phenotypes of $D f(16) 1 /+$ mice. Thus, presynaptic SERCA2 upregulation may be a pathogenic event contributing to the cognitive symptoms of 22q11DS.

\section{Introduction}

The most common microdeletion syndrome in humans is $22 \mathrm{q} 11$ deletion syndrome (22q11DS), also known as velocardiofacial syndrome or DiGeorge syndrome, which occurs in $\sim 1$ of every 4000 live births (Oskarsdóttir et al., 2004). The syndrome is caused by a hemizygous deletion of a $1.5-3 \mathrm{Mb}$ region within chromosome 22q11.2. Children with 22q11DS have a high incidence of mild to moderate cognitive defects and learning disabilities (Eliez et al., 2000; Swillen et al., 2000; Bearden et al., 2001). During adolescence or early adulthood, cognitive functions deteriorate (Gothelf et al., 2007), and schizophrenia or schizoaffective disorder develops in $\sim 30 \%$ of patients (Pulver et al., 1994; Chow et al., 2006).

The orthologous region of the human 22q11.2 locus lies on mouse chromosome 16 . With one exception, all of the human genes in this region are represented in the mouse, although they are organized in a different order (Puech et al., 1997). In recent years, the generation of several mouse models that carry chromosomal deficiencies that are syntenic to the human $22 \mathrm{q} 11.2 \mathrm{mi}$ -

Received March 18, 2010; revised Sept. 16, 2010; accepted Sept. 23, 2010.

This work was supported in part by the Kinship Foundation (Searle Scholars Program), Whitehall Foundation, National Institute of Mental Health Grant R01 MH079079, and the American Lebanese Syrian Associated Charities (S.S.Z.). E.I. was supported by the Dulbecco Telethon Institute. We thank Sharon Frase, Linda Mann, and Jackie Williams for their help with electron microscopy experiments and Angela McArthur for editing this manuscript. The funding sources had no role in study design, data collection and analysis, decision to publish, or preparation of the manuscript.

*L.R.E., I.T.B., and R.G.F. contributed equally to this work.

Correspondence should be addressed to Stanislav S. Zakharenko, Department of Developmental Neurobiology, MS 323, St. Jude Children's Research Hospital, 262 Danny Thomas Place, Memphis, TN 38105. E-mail: stanislav.zakharenko@stjude.org.

DOI:10.1523/JNEUROSCI.1425-10.2010

Copyright $\odot 2010$ the authors $\quad 0270-6474 / 10 / 3015843-13 \$ 15.00 / 0$ crodeletion have been reported (Lindsay et al., 1999; Merscher et al., 2001; Mukai et al., 2008).

$D f(16) 1 /+$ mice carry a hemizygous deletion of 23 genes in the 22q11DS-related region of mouse chromosome 16 (Paylor et al., 2001). These animals exhibit cognitive defects in the conditioned contextual fear paradigm, an assay that partially depends on the hippocampus (Kim and Fanselow, 1992; Phillips and LeDoux, 1992). Abnormal development of dendrites and dendritic spines in hippocampal pyramidal neurons has been reported in another mouse model of 22q11DS (Mukai et al., 2008). Several reports have also indicated that the gross morphology of the hippocampus is affected in patients with 22q11DS (Eliez et al., 2001; Chow et al., 2002; Debbané et al., 2006; Deboer et al., 2007), and this abnormality positively correlates with cognitive impairment (Deboer et al., 2007). Thus, behavioral and morphological studies point to the hippocampus as a brain region affected in 22q11DS. Hippocampal synaptic plasticity, the activity-dependent change in synaptic efficacy, is believed to be important for information storage, fine-tuning of synaptic connections, and certain forms of learning and memory (Milner et al., 1998; Martin et al., 2000). However, whether the 22q11.2 deletion causes changes in synaptic plasticity and whether these changes progress with age similar to symptoms in patients with 22q11DS remains unknown.

Here, we present evidence that synaptic plasticity, in the form of long-term potentiation (LTP) at excitatory synapses between CA3 and CA1 pyramidal neurons (CA3-CA1 synapses), is substantially altered in mature but not young $D f(16) 1 /+$ mice. The underlying cellular mechanisms involve dysregulation of presynaptic calcium $\left(\mathrm{Ca}^{2+}\right)$ and enhanced neurotransmitter release from presynaptic terminals, whereas postsynaptic function and structure remain normal. Additional molecular experiments re- 
vealed that the level of sarco(endo)plasmic reticulum $\mathrm{Ca}^{2+}$ ATPase type 2 (SERCA2) protein is increased in mature but not young $D f(16) 1 /+$ mice. Pharmacological inhibition of SERCA rescued the enhanced neurotransmitter release and LTP in mature mutant mice, indicating that dysregulation of presynaptic $\mathrm{Ca}^{2+}$ causes the observed synaptic phenotypes in the $D f(16) 1 /+$ mouse model of 22q11DS.

\section{Materials and Methods}

Animals. Young (6-8 weeks) and mature (16-20 weeks) $D f(16) 1 /+$ male and female mice and their respective gender-controlled wild-type (WT) littermates were used. Mice were maintained on the C57BL/6 genetic background for at least nine generations. The care and use of animals were reviewed and approved by the Institutional Animal Care and Use Committee of St. Jude Children's Research Hospital.

Brain slice preparation. Acute transverse hippocampal slices $(400 \mu \mathrm{m})$ were prepared as previously described (Bayazitov et al., 2007). Briefly, mouse brains were quickly removed and placed in cold $\left(4^{\circ} \mathrm{C}\right)$ dissecting artificial CSF (ACSF) containing $125 \mathrm{~mm}$ choline-Cl, $2.5 \mathrm{~mm} \mathrm{KCl}, 0.4 \mathrm{~mm}$ $\mathrm{CaCl}_{2}, 6 \mathrm{~mm} \mathrm{MgCl}_{2}, 1.25 \mathrm{~mm} \mathrm{NaH}_{2} \mathrm{PO}_{4}, 26 \mathrm{~mm} \mathrm{NaHCO}_{3}$, and $20 \mathrm{~mm}$ glucose (285-295 mOsm), under $95 \% \mathrm{O}_{2} / 5 \% \mathrm{CO}_{2}$. After dissection, slices were incubated for $1 \mathrm{~h}$ in ACSF containing $125 \mathrm{~mm} \mathrm{NaCl}, 2.5 \mathrm{~mm}$ $\mathrm{KCl}, 2 \mathrm{~mm} \mathrm{CaCl}_{2}, 2 \mathrm{~mm} \mathrm{MgCl}_{2}, 1.25 \mathrm{~mm} \mathrm{NaH}_{2} \mathrm{PO}_{4}, 26 \mathrm{~mm} \mathrm{NaHCO}_{3}$, and $10 \mathrm{~mm}$ glucose (285-295 mOsm), under $95 \% \mathrm{O}_{2} / 5 \% \mathrm{CO}_{2}$ at room temperature, and then transferred into the submerged recording chamber and superfused $(2-3 \mathrm{ml} / \mathrm{min})$ with warm $\left(30-32^{\circ} \mathrm{C}\right)$ ACSF.

Field potential recordings. The field recordings were performed using a setup with eight submerged recording chambers (Campden Instruments). Recordings in each chamber were performed independently. We recorded field EPSPs (fEPSPs) from the CA1 stratum radiatum by using an extracellular glass pipette (3-5 M $\Omega$ ) filled with ACSF. Schaffer collateral fibers in the stratum radiatum were stimulated with a bipolar tungsten electrode placed $200-300 \mu \mathrm{m}$ away from the recording pipette. Stimulation intensities were chosen to produce an fEPSP with a $0.5 \mathrm{~V} / \mathrm{s}$ slope. Paired-pulse facilitation (PPF) experiments were performed using a pair of stimuli of the same intensity delivered 20, 50, 100, 200, and 1000 ms apart.

LTP was induced by three periods of $200 \mathrm{~Hz}$ tetanization delivered every $5 \mathrm{~min}$. Every period of tetanization consisted of 10 trains of $200 \mathrm{~Hz}$ stimulation delivered at the same intensity for $200 \mathrm{~ms}$ (40 stimulations) every $5 \mathrm{~s}$. A similar protocol has previously been used to induce compound (presynaptic and postsynaptic) LTP at CA3-CA1 synapses in the hippocampus (Cavus and Teyler, 1996; Zakharenko et al., 2001, 2003).

Whole-cell electrophysiology. Whole-cell recordings were obtained from the cell bodies of CA1 and CA3 neurons. For current-clamp recordings, patch pipettes (open pipette resistance, $3-5 \mathrm{M} \Omega$ ) were filled with an internal solution containing $140 \mathrm{mM} \mathrm{KMeSO}_{4}, 8 \mathrm{~mm} \mathrm{NaCl}, 1 \mathrm{~mm} \mathrm{MgCl}$, 10 mm HEPES, 5 mм MgATP, $0.4 \mathrm{~mm} \mathrm{Na}_{2}$ GTP, $300 \mu \mathrm{m}$ Fluo 5F, and $10-25 \mu \mathrm{M}$ Alexa 594, pH 7.3. For voltage-clamp recordings, we replaced the potassium-based solution with a cesium-based internal solution. Whole-cell recordings were registered using a Multiclamp 700B (Molecular Devices), digitized (10 kHz; DigiData 1322A; Molecular Devices), and recorded using pCLAMP 9.0 software (Molecular Devices). Spontaneous miniature EPSCs (mEPSCs) were recorded at $-70 \mathrm{mV}$ holding potential in the presence of picrotoxin $(100 \mu \mathrm{M})$ and tetrodotoxin $(1 \mu \mathrm{M})$ in the extracellular solution for at least $1 \mathrm{~h}$. Amplitude, $10-90 \%$ rise time, $90-10 \%$ decay time, and interevent intervals of mEPSCs were analyzed off-line using the Mini-Analysis Program (Synaptosoft). All detected events were verified visually, and events with amplitudes $<5$ pA were rejected. Evoked EPSCs were recorded in the presence of QX-314 (lidocaine $N$-ethyl bromide) ( $5 \mathrm{~mm}$ ) in the intracellular solution to block the generation of backpropagating action potentials (APs) and picrotoxin in the extracellular solution to block inhibitory transmission. EPSCs were evoked at $0.1 \mathrm{~Hz}$ with a bipolar electrode placed in the stratum radiatum $200-300 \mu \mathrm{m}$ from the recording pipette and $100-150 \mu \mathrm{m}$ from the soma. The amplitude of stimulation was adjusted to evoke $100 \mathrm{pA}$ EPSCs at $-70 \mathrm{mV}$. To determine the average amplitude, rise and decay times, we collected 10-20 EPSCs (interstimulus interval, $>10$ s) from each neuron.
In whole-cell short-term plasticity (STP) experiments, neurons were held at $-70 \mathrm{mV}$, and 10 stimulations at different frequencies were applied to Schaffer collaterals. Data were analyzed by normalizing all EPSCs in the train to the amplitude of the first EPSC. The current ratio of AMPA receptors to NMDA receptors (AMPAR/NMDAR) was calculated from the EPSC traces recorded at $+40 \mathrm{mV}$. The amplitude of stimulation was adjusted to evoke $50 \mathrm{pA}$ EPSCs at $-70 \mathrm{mV}$. The AMPAR current was determined at time points when EPSCs recorded at $-70 \mathrm{mV}$ reached their peaks, and the NMDAR currents were determined $100 \mathrm{~ms}$ after the peaks. EPSCs were analyzed off-line using Clampfit 10.1 software (Molecular Devices).

Two-photon imaging. Two-photon laser-scanning microscopy (TPLSM) was performed using an Ultima imaging system (Prairie Technologies), a Ti:sapphire Chameleon Ultra femtosecond-pulsed laser (Coherent), and $60 \times$ [numerical aperture (NA), 0.9] water-immersion infrared (IR) objectives (Olympus). Alexa Fluor 594 and Fluo 5F were included in the internal solution (see above) and were excited at $820 \mathrm{~nm}$.

Alexa 594 fluorescence ( $\mathrm{R}$, red channel) was used to image and reconstruct dendritic morphology of CA1 neurons and axonal morphology of CA3 neurons. ImageJ was used to analyze dendritic branching and morphology of dendritic spines. Changes in Fluo $5 \mathrm{~F}$ fluorescence ( $\mathrm{G}$, green channel) were used to visualize changes in $\mathrm{Ca}^{2+}$ concentrations in dendritic spines and presynaptic terminals. Synaptically evoked changes in the fluorescence of Fluo $5 \mathrm{~F}$ were measured in current clamp using linescan mode $(500 \mathrm{~Hz})$ in dendritic spines. Fluorescence changes were quantified as an increase in Fluo $5 \mathrm{~F}$ fluorescence normalized to the average Alexa 594 fluorescence $(\Delta G / R)$ (Yasuda et al., 2004). To identify synaptic inputs, we took multiple scans through the apical part of secondary or tertiary dendrites (50-150 $\mu \mathrm{m}$ from a soma) of CA1 neurons in current-clamp mode in response to synaptic stimulation. Stimulation intensity was adjusted to evoke $50-100 \mathrm{pA}$ in voltage-clamp mode. Dendritic sites responding with maximal Fluo $5 \mathrm{~F}$ transients to synaptic stimulation were chosen for imaging, and line scans through corresponding dendritic spines were taken. We measured calcium transients in a single dendritic site on each recorded neuron. $\mathrm{Ca}^{2+}$ transients in CA3 presynaptic terminals were recorded in a similar fashion. Axons were identified based on Alexa 594 fluorescence as thin processes that emanated from cell bodies and had no dendritic spines. Presynaptic terminals were identified as boutons situated along axons. $\mathrm{Ca}^{2+}$ transients in presynaptic boutons were recorded in line-scan mode and were evoked by injection of a depolarizing current $(0.5 \mathrm{~ms}, 1.2-2.5 \mathrm{nA})$ that evoked an AP in the recorded neuron. The number of evoked APs was controlled on-line in current-clamp mode. We recorded from two to four boutons on each neuron and measured the calcium transients in each bouton independently. When $40 \mathrm{APs}$ at $200 \mathrm{~Hz}$ were delivered to a presynaptic bouton, the following precautions were taken: we monitored that 40 pulses evoked $40 \mathrm{APs}$ in a recorded neuron, and Fluo $5 \mathrm{~F}$ fluorescence in presynaptic terminals did not saturate. After delivery of $40 \mathrm{APs}$ at $200 \mathrm{~Hz}$, we depolarized neurons to $+20 \mathrm{mV}$ and measured the Fluo 5F fluorescence in the same bouton. The maximal increase in Fluo $5 \mathrm{~F}$ fluorescence in presynaptic boutons was $63 \pm 18 \%$ higher during $+20 \mathrm{mV}$ depolarization than that during $200 \mathrm{~Hz}$ tetanization $(p=0.03 ; n=3)$, indicating that the dye was not saturated during these experiments.

FM 1-43 assay in acute hippocampal slices. The FM 1-43 assay was performed as a modification of the method described previously (Zakharenko et al., 2002, 2003). FM 1-43 (10 $\mu \mathrm{M})$ was washed into acute slices for 20-30 min. Loading of presynaptic boutons was performed by using $10 \mathrm{~Hz}$ synaptic stimulation for $2 \mathrm{~min}$ in the presence of D-APV (50 $\mu \mathrm{M}$; Tocris Bioscience) to avoid synaptic plasticity. ADVASEP-7 (200 $\mu \mathrm{M}$; Biotium) was then washed in for 20-30 min to remove the extracellular FM 1-43 dye. Loaded presynaptic boutons were visualized using TPLSM $(900 \mathrm{~nm})$. A series of four images at different focal planes was acquired every $5 \mathrm{~s}$. Each image was $512 \times 512$ pixels $(33.6 \times 33.6 \mu \mathrm{m})$, $0.066 \mu \mathrm{m} /$ pixel in the $x-y$ axes, and images were separated by $1 \mu \mathrm{m}$ steps in the $z$ direction.

Images in each $z$-section series were aligned and analyzed using custom software written in Interactive Data Language (IDL; ITT Visual Information Solutions). The area of the slice in which fluorescent puncta were analyzed was restricted to the area within $50-150 \mu \mathrm{m}$ 
from the pyramidal layer and corresponded to the areas of the apical dendrites where $\mathrm{Ca}^{2+}$ experiments were conducted. Images showing projections of maximal $z$-axis intensity were made for each subset of a given stack. Puncta were initially identified by a semiautomated procedure written in IDL based on two criteria: (1) fluorescence intensity $>2 \times$ SDs above the mean background and (2) diameter between 0.3 and $1.8 \mu \mathrm{m}$.

Fluorescence measurements were made by spatially averaging signals over a region centered over each of the identified puncta for each time point during the unloading protocol. Images at successive time points were checked for overlap to help track puncta, which underwent small random movements. Puncta that underwent considerable lateral movement or $>20 \%$ loss of their fluorescent intensity without synaptic stimulation because of photobleaching were excluded from the analysis. The spatially averaged fluorescence intensity of each punctum obtained at each time point during the unloading procedure was then normalized by the initial fluorescence intensity of that punctum. The unloading procedure consisted of 10 trains of tetanic synaptic stimulations (same as the LTP induction protocol). Each train consisted of 40 stimulations delivered at $200 \mathrm{~Hz}$. This unloading procedure followed by $10 \mathrm{~Hz}$ stimulation was applied for 2 min to maximally release FM 1-43 from boutons. Decay of intensity during the $200 \mathrm{~Hz}$ unloading procedure was fitted to a single exponential function by using a custom-made routine written in IDL, and FM 1-43 destaining half-time $\left(t_{1 / 2}\right)$ for every punctum was calculated. The rate of destaining for each punctum was expressed as $1 / t_{1 / 2}$. Puncta for which fluorescence intensities during unloading could not be fitted to a single exponential function were not included in the analysis.

Two-photon glutamate uncaging. 4-Methoxy-7-nitroindolinyl (MNI)glutamate (2.5 mM; Tocris Bioscience) was added to the recording ACSF. MNI-glutamate was uncaged by using TriggerSync (Prairie Technologies) and by $0.2-0.5 \mathrm{~ms}$ pulses that were delivered from a second Ti: sapphire Chameleon Ultra femtosecond-pulsed laser (Coherent) at 720 $\mathrm{nm}$. The intensity and duration of the uncaging laser was adjusted to mimic mEPSPs $(0.4-0.5 \mathrm{mV})$ or mEPSCs $(10-12 \mathrm{pA})$. In all experiments, before each uncaging pulse, an image of the spine was acquired and automatically aligned with a reference image of the spine. The uncaging laser intensity was normalized to the same degree of Alexa 594 bleaching by using the previously described method to deliver the same photostimulation power to individual dendritic spines, independent of the depth of the spine in the slice or the refraction index of local tissue (Bloodgood and Sabatini, 2005). Once the duration and laser power were adjusted, we delivered six to nine test pulses around the perimeter of a spine head to determine the optimal site of uncaging (determined as the maximal response). Another test pulse to the center of the spine head determined the level of Alexa 594 bleaching. We then uncaged MNI-glutamate at the optimal site. The level of Alexa 594 bleaching was used to adjust the laser power (but not duration) for other dendritic spines of the same neuron. The pointspread function of the focal volume of two-photon excitation was 300 $\mathrm{nm}$ laterally and $1100 \mathrm{~nm}$ axially (NA, 0.9) based on images of $100 \mathrm{~nm}$ fluorescent beads.

Spatial memory testing. We tested spatial memory in the Morris water maze. We used a circular steel water maze (diameter, 4 feet; depth, 2 feet) filled with water (room temperature) clouded with white, nontoxic, water-based paint. Compass points labeled along the rim served as trial starting positions. For the spatial tasks, water levels were raised 0.25 in above the clear, Plexiglas escape platform. For the nonspatial task, the water level was lowered so that the escape platform was visible 0.25 in above the surface of the water. The water maze environment was full of visual cues whose locations remained fixed throughout the learning protocol. Mouse movements in the maze were recorded using a video camera tracking system (HVS Image) mounted above the pool, and path length was measured. Animals learned to find a hidden platform in the training (TRA) quadrant using the standard spatial version of the Morris water maze task for 10 successive days. Each day, animals were given four $1 \mathrm{~min}$ trials from each starting position with an intertrial latency of at least $60 \mathrm{~s}$. The order of starting locations was counterbalanced each day using a Latin square design.
A spatial memory (probe) trial was administered on the day after the completion of spatial learning. With the platform removed, animals received a single $1 \mathrm{~min}$ trial in which the animal tried to find the escape platform in the TRA quadrant. This trial started from the point that was the farthest from the location of the platform on the previous training day. The overall path length was measured for each mouse, and the relative path length for each quadrant was calculated.

Mice started nonspatial learning tasks at least $8 \mathrm{~d}$ after completion of the spatial protocol. In this task, the platform was visible above the surface of the water. Animals were trained using the standard nonspatial version of the Morris water maze task for 5 successive days. During training day 1 , they saw the escape platform located in the same position used during spatial training. Each day thereafter, the escape platform was rotated, in a clockwise manner, to the next quadrant. Each day, animals were given four $1 \mathrm{~min}$ trials in the same manner that occurred during spatial training.

Electron microscopy. Hippocampal slices were fixed in $2.5 \%$ glutaraldehyde in $0.1 \mathrm{~m}$ sodium cacodylate buffer, thrice rinsed in the same buffer, and dehydrated in a graded series of alcohol and then propylene oxide washes. The tissue was infiltrated and embedded in Epon Araldite and polymerized overnight at $70^{\circ} \mathrm{C}$. We cut $70 \mathrm{~nm}$ sections on a Leica UC6 ultramicrotome fitted with a Diatome diamond knife and stained with lead citrate and $8 \%$ uranyl acetate. Thick sections were trimmed to a region between the CA1 and dentate gyrus cell body layers, and the somata were used as guideposts to find the CA1 area where synapses were identified. The sections were imaged on a JEOL 1200EX11 transmission electron microscope with an AMT XR111 11 megapixel digital camera. Synapses were counted as regions of membrane enclosing synaptic vesicles in close proximity to a postsynaptic density. Vesicle size and number and postsynaptic density length were measured in ImageJ by tracing with the line or elliptical selection tools followed by measurement.

Quantitative real-time PCR. RNA was isolated from the hippocampi of 4-month-old WT mice and heterozygous $D f(16) 1 /+$ littermates (three to five mice per genotype) using the mirVana RNA isolation kit (Applied Biosystems). The SuperScript III reverse transcriptase kit (Invitrogen) was used to synthesize cDNA from $1 \mu \mathrm{g}$ of RNA. Primers were as follows: Gapdh, GTCGGTGTGAACGGATTTG and TAGACTCCACGACATACTCAGCA; Tbxl, GTCACTGCCTACCAGAATCAC and TCCGAGAGCGAGCAAAGG; and Serca2b, GCCGTTTGTGCTGCTCATTATG and AACCTCCTTCACCAGCCAATATG. Quantitative real-time PCR was conducted using an Applied Biosystems 7900HT Fast Real-Time PCR System and the standard protocol $\left(50^{\circ} \mathrm{C}\right.$ for $2 \mathrm{~min}, 95^{\circ} \mathrm{C}$ for $10 \mathrm{~min}$, then 40 cycles of $95^{\circ} \mathrm{C}$ for $15 \mathrm{~s}$ and $60^{\circ} \mathrm{C}$ for $1 \mathrm{~min}$ ). Standard curves were generated from a reference sample and used to obtain expression levels of each gene. Expression levels of Serca $2 b$ and the positive control gene Tbx 1 , which is contained in the deletion region, were normalized to the housekeeping gene Gapdh for each sample. Samples for each mouse were run in duplicate.

Western blotting. Hippocampi were dissected at $4^{\circ} \mathrm{C}$ and prepared either as whole-tissue lysates or as crude synaptosomal fractions (P2). Synaptosomes were prepared as previously described (Gray and Whittaker, 1962). In brief, fresh tissue was homogenized in $10 \mathrm{~mm} \mathrm{HEPES,} \mathrm{pH}$ 7.4, and $0.32 \mathrm{~m}$ sucrose by using a motorized glass-Teflon homogenizer. To separate the P2 synaptosomal fraction, the homogenate was spun for $5 \mathrm{~min}$ at $800 \times g$, the supernatant was then centrifuged for $20 \mathrm{~min}$ at $12,000 \times g$. Tissue or synaptosomal pellets were lysed by freezing and thawing, subsequent syringe passage in ice-cold RIPA buffer [50 mM Tris-HCl, pH 7.4, 1\% NP-40, 0.25\% sodium deoxycholate, $150 \mathrm{~mm}$ $\mathrm{NaCl}, 1 \mathrm{~mm}$ EDTA, and protease inhibitor mixture tablets (Roche)], and finally brief sonication. The concentrations of protein lysates were determined by BCA assay (Thermo Fisher Scientific). A $25 \mu \mathrm{g}$ sample of each protein extract was electrophoresed on a 10\% SDS-PAGE gel, and protein was transferred to polyvinylidene difluoride membranes (Invitrogen). The primary antibodies used were goat anti-SERCA2 (1:250; sc-8095; Santa Cruz Biotechnology), mouse anti- $\beta$-actin (1:10,000; A5316; Sigma-Aldrich), rabbit anti-synaptophysin (1:1000; Invitrogen), and rabbit anti-NR2A (1:1000; G9038; Sigma-Aldrich). Blots for synaptophysin and NR2A were probed with HRP-conjugated secondary antibodies and imaged using enhanced chemiluminescence detection by film. SERCA and $\beta$-actin Western blots were probed with anti-mouse 
(1:5000) and anti-goat (1:5000) secondary antibodies conjugated to IR dye 680 or 800 (LICOR Biosciences). These blots were imaged and quantified using the Odyssey infrared imaging system (LI-COR Biosciences). Because this system has a broad linear detection range (10-100,000), the $\beta$-actin signal (range, 100300 ) did not saturate beyond detection limits, allowing for accurate normalization of SERCA levels to the loading control within the same lane.

Drugs. Drugs were purchased from SigmaAldrich, except cyclopiazonic acid (CPA) and thapsigargin, which were purchased from Tocris Bioscience.

Statistics. All data are represented as mean \pm SEM. Statistics for all experiments, except behavioral testing studies, were computed using nonparametric Mann-Whitney rank sum and Wilcoxon's signed rank tests or $t$ test measured in SigmaStat (Systat Software). Statistics for behavioral testing were computed using repeated-measures ANOVA measured in SPSS Statistics (SPSS).

\section{Results}

\section{Hippocampal LTP is enhanced in mature but not in young $D f 16(1) /+$ mice}

To examine whether the $D f(16) 1$ deletion affects LTP at excitatory CA3-CA1 synapses, we recorded fEPSPs before and after the delivery of a $200 \mathrm{~Hz}$ tetanus to the Schaffer collaterals in acute brain slices from WT and mutant mice. Because this induction protocol potentiates both neurotransmitter release and postsynaptic responses at CA3-CA1 synapses (Zakharenko et al., 2001; Bayazitov et al., 2007), we reasoned that it would reveal changes in both presynaptic and postsynaptic components of LTP. Because patients with 22q11DS manifest a decline in cognitive function (Gothelf et al., 2007), we tested LTP in mice of two different ages. We found that LTP was not substantially altered in younger (6-8 weeks) $D f(16) 1 /+$ mice compared with WT littermates ( $p=0.174 ; 43-45$ slices; eight mice per genotype) (Fig. $1 a)$. In contrast, more mature (16-20 weeks) $D f(16) 1 /+$ mice exhibited dramatically enhanced posttetanic potentiation (PTP) and LTP (Fig. 1b). The PTP of fEPSPs measured 5 min after tetanization $\left(\mathrm{fEPSP}_{5}\right.$ ) was $\sim 120 \%$ higher in mature $D f(16) 1 /+$ mice than in WT mice, increasing to $347.9 \pm 35.3 \%$ over baseline, compared with $156 \pm 14.6 \%$ in WT littermates $(p<0.001 ; 24-29$ slices; six to eight mice). In mature WT mice, LTP of fEPSPs measured $6 \mathrm{~h}$ posttetanus $\left(\mathrm{fEPSP}_{360}\right)$ showed a $39.3 \pm 10.5 \%$ increase over baseline, whereas in $D f(16) 1 /+$ littermates, the fEPSP $_{360}$ was $\sim 200 \%$ higher than in WT mice and showed a $118.4 \pm 19.7 \%$ increase over baseline ( $p<0.001 ; 24-29$ slices; six to eight mice). Changes in LTP were not attributable to an increase in the number of stimulated afferents, because no changes in fiber volley were detected in mature $D f(16) 1 /+$ or WT mice (supplemental Fig. S1, available at www.jneurosci.org as supplemental material).

Along with developmental changes in LTP, Df(16)1/+ mice showed age-dependent deficits in the hippocampusdependent spatial behavioral task, the Morris water maze. Young $D f(16) 1 /+$ mice did not show any difference in spatial memory compared with their WT littermates (supplemental Fig. S2a, available at www.jneurosci.org as supplemental material).
However, mature $D f(16) 1 /+$ mice showed deficient spatial memory (supplemental Fig. S2b, available at www.jneurosci.org as supplemental material), whereas spatial learning and nonspatial memory remained intact (supplemental Fig. $\$ 2 c, d$, available at www.jneurosci.org as supplemental material). These results demonstrate that $D f(16) 1 /+$ mice develop a deficit in hippocampus-dependent spatial memory that coincides with the onset of LTP abnormalities.

To determine the cause of the substantial increase in LTP in mature $D f(16) 1 /+$ mice, we first tested for differences in basal synaptic transmission. However, input-output coupling at CA3CA1 synapses did not significantly differ between mature $D f(16) 1 /+$ mice and WT littermates ( $p>0.05 ; 24-29$ slices; six to eight mice) (Fig. 1c). Similarly, single-cell recording revealed no differences in spontaneous or evoked EPSCs in mature $D f(16) 1 /+$ mice. Amplitudes of spontaneous mEPSCs (18.01 \pm $1.28 \mathrm{pA}$ for $D f(16) 1 /+$ and $17.73 \pm 1.03 \mathrm{pA}$ for $\mathrm{WT} ; p=0.87$; six to seven neurons, 551-2445 events per neuron), as well as intervals between mEPSCs $(4.78 \pm 0.77 \mathrm{~s}$ for $\mathrm{Df1}(16) /+$ and $3.81 \pm$ $0.74 \mathrm{~s}$ for WT; $p=0.135$; six to seven neurons) were not significantly different between the genotypes (Fig. 1d). Rise times $(2.39 \pm 0.11 \mathrm{~ms}$ for $D f 1(16) /+$ and $2.47 \pm 0.14 \mathrm{~ms}$ for WT mice; $p=0.29)$ and decay times $(6.38 \pm 0.22 \mathrm{~ms}$ for $D f(16) 1 /+$ and $6.50 \pm 0.34 \mathrm{~ms}$ for WT mice; $p=0.25$; six to seven neurons) of mEPSCs were also not different in mutant and WT mature mice. Similarly, rise times and decay times of EPSCs evoked by a single synaptic stimulation were not significantly different between mature $D f(16) 1 /+$ and WT littermates $(p=0.29$ and 0.49 , respectively; 10 neurons per genotype) (Fig. $1 e$ ). These data indicate that basal synaptic transmission is normal at excitatory synapses of $D f(16) 1 /+$ mice, whereas LTP mechanisms undergo substantial developmental changes in the $D f(16) 1 /+$ model of 22q11DS. 
a

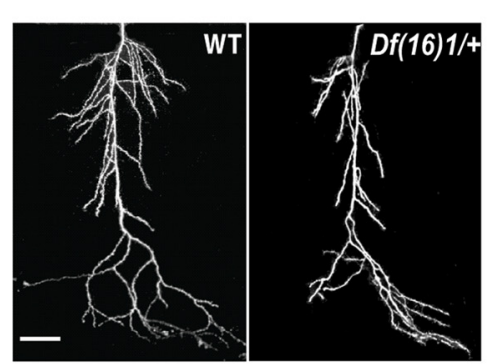

C

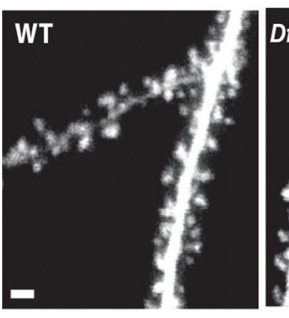

e

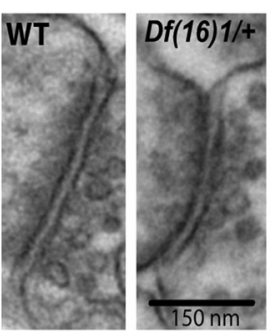

i

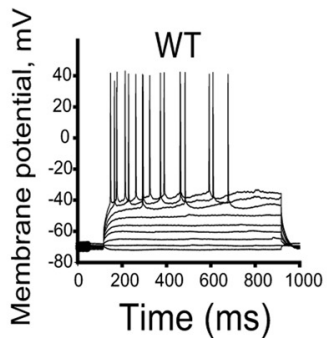

b

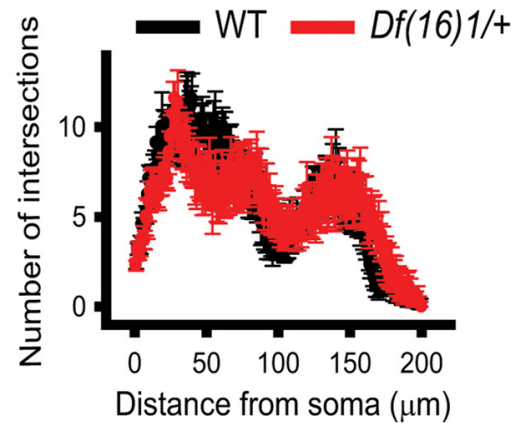

d
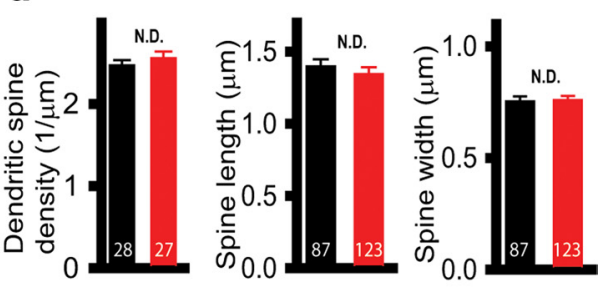

g
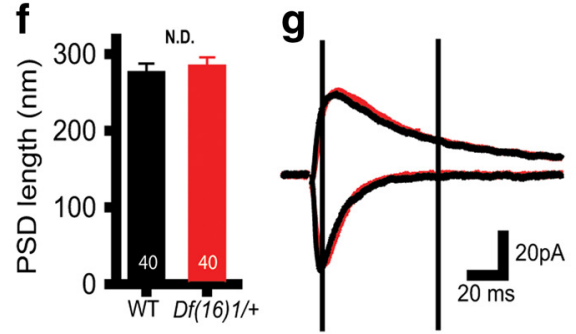

h

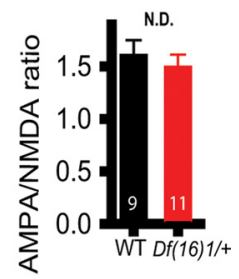

j
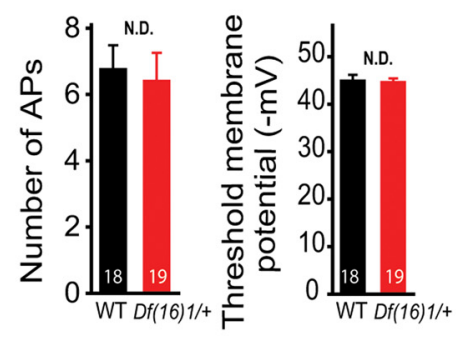

Figure 2. Structure and function of postsynaptic neurons are not affected by the $D f(16) 1$ microdeletion in mature mice. $\boldsymbol{a}$, Representative images of the apical dendrites of CA1 neurons from slices of WT (left) and Df(16)1/+ (right) littermates. Scale bar, $50 \mu \mathrm{m} . \boldsymbol{b}$, Scholl analysis of apical dendritic tree branching of CA1 neurons in WT and Df(16)1/+ mice. c, Representative TPLSM images of dendritic spines in CA1 neurons of WT (left) and Df(16)1/+ (right) mice. Scale bar, $2 \mu \mathrm{m}$. $d$, Mean dendritic spine density (27-28 dendrites), length, and width (87-123 randomly selected spines) on CA1 neurons from WT and Df(16)1/+ mice. $\boldsymbol{e}, \boldsymbol{f}$, Representative electron micrographs $(\boldsymbol{e})$ and mean lengths of postsynaptic densities $(\boldsymbol{f})$ at synapses in the CA1 areas of WT and Df(16)1/+ mice. $\boldsymbol{g}, \boldsymbol{h}$, Representative traces of AMPAR-mediated (recorded at $-70 \mathrm{mV}$, downward traces) and NMDAR-mediated (recorded at $+40 \mathrm{mV}$, upward traces) EPSCs $(\boldsymbol{g})$ and the mean ratio of AMPA/NMDA currents $(\boldsymbol{h})$ recorded at CA3-CA1 synapses from WT and mutant mice. $\boldsymbol{i}$, Representative traces of changes in the membrane potentials in CA1 neurons in response to injection of currents of different amplitudes ( $-25-225 \mathrm{pA}$; increment, $25 \mathrm{pA})$. $\boldsymbol{j}$, Average number of APs fired in response to a $75 \mathrm{pA}$ depolarization current and average threshold membrane potential required for generation of APs in CA1 neurons of WT and Df(16) $1 /+$ mice.

\section{Dendritic morphology and postsynaptic function are preserved in mature $D f 16(1) /+$ mice}

Previous studies have reported structural abnormalities in the brains of 22q11DS mouse models (Mukai et al., 2008; Stark et al., 2008; Meechan et al., 2009); thus, we asked whether developmental changes in synapse structure contribute to the enhanced LTP in mature $D f(16) 1 /+$ mice. We visualized dendritic structures by loading CA1 pyramidal neurons of mature mice with the fluorescent dye Alexa 594 through a whole-cell pipette and imaging them using TPLSM. The overall morphology of apical dendritic trees of CA1 neurons from mature $D f(16) 1 /+$ mice was indistinguishable from that of WT littermates, and quantification of branching by Scholl analysis revealed no difference between genotypes ( $p=0.863$; seven to nine neurons) (Fig. $2 a, b)$. Furthermore, the length $(p=0.21)$, width $(p=0.84)$, and density $(p=0.36)$ of dendritic spines were similar between mutants and WT littermates (five to seven neurons; 27-28 dendrites; 1171-1290 spines) (Fig. 2c,d). We further used electron microscopy to resolve synapses and subsynaptic structures in this region. However, this analysis revealed no abnormalities in the number of CA1 synapses, the number of vesicles, or the size of the postsynaptic densities of mature $D f(16) 1 /+$ mice (Fig. $2 e$; supplemental Fig. S3, available at www.jneurosci.org as supplemental material). The only significant change was a slight increase in synaptic vesicle diameter in $D f(16) 1 /+$ synapses (30.97 \pm $0.27 \mathrm{~nm}$ ) compared with that of WT synapses $(29.18 \pm 0.31 \mathrm{~nm}$; 60-80 synapses; $p=0.005)$. However, this change did not affect neurotransmitter release, because the amplitude of spontaneous mEPSCs was not affected in mature $D f(16) 1 /+$ mice (Fig. 1d).

Similarly, electrophysiological characteristics of postsynaptic neurons were not altered in mature $D f(16) 1 /+$ mutants (Fig. $2 g-j$ ). AMPAR/NMDAR ratios measured in CA1 neurons of $D f(16) 1 /+$ and WT mice were not significantly different ( $p=0.53$; $9-11$ neurons). There was no difference in the resting membrane potentials $(-65.8 \pm 0.8 \mathrm{mV}$ for $\mathrm{WT}$ and $-66.2 \pm 1.1 \mathrm{mV}$ for $D f(16) 1 /+$ mice; 15 neurons per genotype; $p=0.78$ ) or in the excitability of CA1 neurons in mature WT and $D f(16) 1 /+$ mice (Fig. 2i). Injection of depolarizing currents evoked a similar number of APs $(p=0.75)$ at similar threshold membrane potentials $(p=0.67$; 18-19 neurons) in mutant and WT mice (Fig. 2j). Thus, these data suggest that morphological or functional changes in postsynaptic CA1 neurons do not contribute to the enhancement of LTP at CA3-CA1 synapses in mature $D f 1(16) /+$ mice.
Short-term synaptic plasticity is enhanced in mature but not young $D f 16(1) /+$ mice

To investigate the presynaptic contribution to the $D f(16) 1 /+$ phenotype, we tested short-term synaptic plasticity, which relies primarily on the presynaptic machinery. To measure PPF of fEPSPs, we recorded field potentials evoked by two synaptic stimulations delivered at different interpulse intervals. We found that PPF in slices from mature $D f(16) 1 /+$ mice was greater than that of WT littermates ( $p<0.01 ; 23-29$ slices/six to eight mice) (Fig. $3 a)$. In contrast, PPF in slices from young $D f 1(16) /+$ mice was 
a

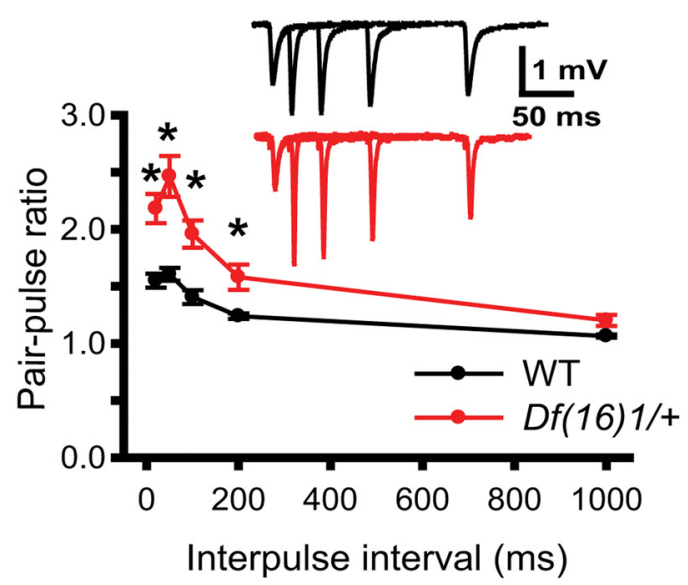

b $\quad 50 \mathrm{~Hz}$

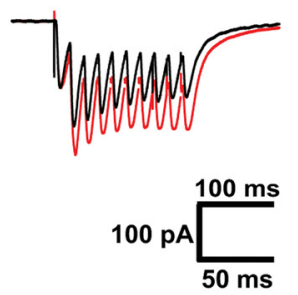

d

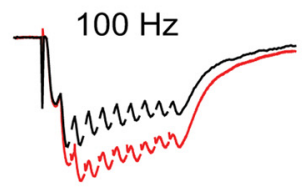

C

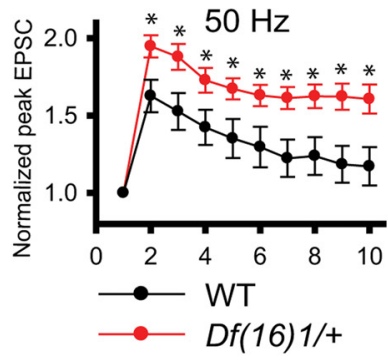

e

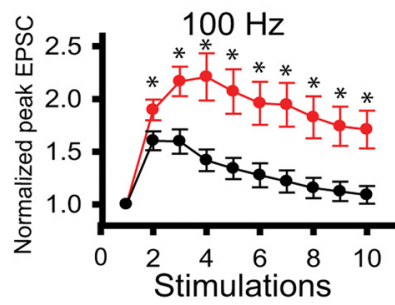

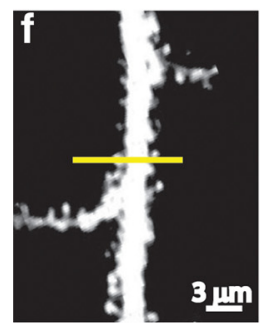
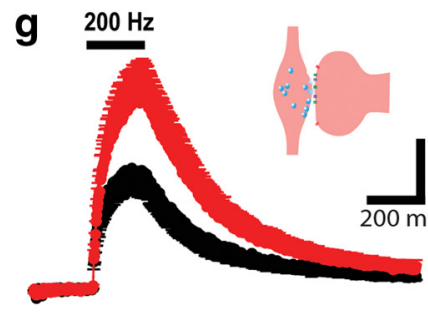

h

Glu $200 \mathrm{~Hz}$
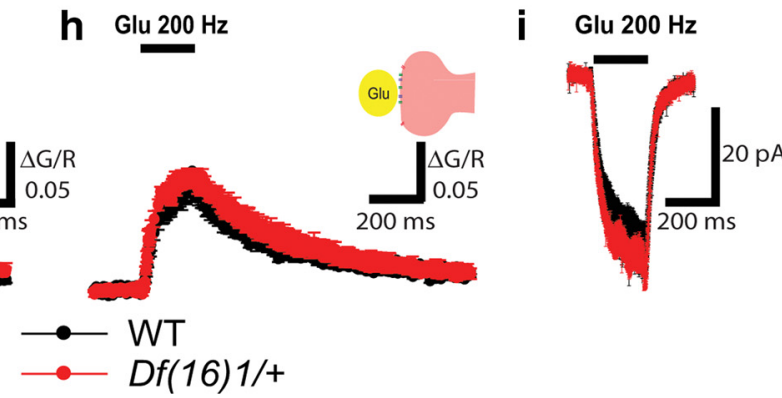

Figure 3. Presynaptic function is affected by the $D f(16) 1$ microdeletion in mature mice. $a, P P F$ is enhanced in mature $D f(16) 1 /+$ mice. Mean fEPSPs as a function of the interstimulus interval (ISI) between the first and second fEPSPs evoked at CA3-CA1 synapses of WT and Df(16)1/+ mice. The inset shows representative traces of pairs of fEPSPs evoked with 20,50, 100, or 200 ms ISIs. $\boldsymbol{b}$ - $\boldsymbol{e}$, Short-term plasticity is enhanced in mature Df(16)1/+ mice. Typical EPSC traces $(\boldsymbol{b}, \boldsymbol{d})$ and mean peak amplitudes of EPSCs $(\boldsymbol{c}, \boldsymbol{e})$ evoked by $50 \mathrm{~Hz}(\boldsymbol{b}, \boldsymbol{c})$ or $100 \mathrm{~Hz}(\boldsymbol{d}, \boldsymbol{e})$ synaptic stimulations in slices from mature WT and $D f(16) 1 /+$ mice $\left({ }^{*} p<0.05\right) . \boldsymbol{f}-\boldsymbol{h}$, Postsynaptic calcium transients evoked by synaptic stimulation but not by TGU are stronger in Df(16)1/+ mice.f, A TPLSM image of a CA1 pyramidal neuron dendrite. The line represents the direction of the line scan. $\boldsymbol{g}, \boldsymbol{h}$, Mean normalized Fluo $5 \mathrm{~F}$ fluorescence $(\Delta G / R)$ in dendritic spines of $C A 1$ neurons as a function of time with 40 synaptic (g) or TGU (h) stimulations delivered at $200 \mathrm{~Hz}$. $\boldsymbol{i}$, Mean EPSCs evoked by 40 pulses of TGU at $200 \mathrm{~Hz}$ at dendritic spines.

not elevated compared with that in slices from WT littermates ( $p>0.05 ; 18-19$ slices/five to six mice) (supplemental Fig. S4a, available at www.jneurosci.org as supplemental material). Using whole-cell recordings in mature animals, we measured EPSC facilitation evoked by trains of synaptic stimulations. Synaptic facilitation during high-frequency stimulation was also substantially enhanced in mature but not young mutant mice. Thus, synaptic facilitation was significantly increased in mature $D f(16) 1 /+$ mice compared with WT littermates if induced by a 50 $\mathrm{Hz}$ stimulation train ( $p<0.05 ; 10-17$ neurons) (Fig. $3 b, c)$ or a $100 \mathrm{~Hz}$ ( $p<0.05 ; 9-17$ neurons) stimulation train (Fig. $3 d, e)$. In contrast, no enhancement of synaptic facilitation was observed in younger $D f(16) 1 /+$ mice ( $p>0.05$; six to eight neurons) (supplemental Fig. S4b,c, available at www.jneurosci.org as supplemental material). Thus, both forms of STP were enhanced in mature mutant mice compared with WT littermates, suggesting that presynaptic function becomes enhanced in $D f 1(16) /+$ mice on maturation.

To further distinguish between contributions from presynaptic and postsynaptic loci to the LTP phenotype of mature $D f 1(16) /+$ mice, we compared $\mathrm{Ca}^{2+}$ transients in dendritic spines of CA1 neurons in response to the LTP induction protocol (40 stimulations at $200 \mathrm{~Hz}$ ) delivered by either synaptic stimulation (tetanus) or two-photon photolysis of caged glutamate. The comparison of the results from these two methods allows for the distinction between presynaptic and postsynaptic function, because two-photon glutamate uncaging (TGU) releases exogenous glutamate, thereby bypassing the release of endogenous neurotransmitters from presynaptic terminals (Matsuzaki et al., 2001). To perform these experiments, we filled CA1 neurons with the $\mathrm{Ca}^{2+}$ indicator Fluo $5 \mathrm{~F}$ and the fluorescent dye Alexa 595 through a whole-cell pipette and measured changes in Fluo $5 \mathrm{~F}$ fluorescence in dendritic spines in current-clamp mode in response to either synaptic stimulation or TGU (Fig. $3 f$ ). To mimic synaptically evoked mEPSPs, we adjusted the uncaging laser power to evoke $0.4-0.5 \mathrm{mV}$ EPSPs in response to a single TGU pulse. $\mathrm{Ca}^{2+}$ transients evoked by the $200 \mathrm{~Hz}$ tetanus (40 stimulations) were substantially larger in mature $D f(16) 1 /+$ mice than in WT mice (Fig. $3 g$ ). On average, during $200 \mathrm{~Hz}$ tetanus, peak $\Delta G / R$ was $0.16 \pm 0.03 \%$ in $D f(16) 1 /+$ mice but only $0.10 \pm$ $0.02 \%$ in WT mice ( $p=0.03 ; 12-15$ neurons). In contrast, $200 \mathrm{~Hz}$ TGU (40 stimulations) produced $\mathrm{Ca}^{2+}$ transients of similar amplitudes in dendritic spines of $D f(16) 1 /+$ and WT mice $(p=0.21$; 7-11 neurons) (Fig. 3h). Kinetics of postsynaptic $\mathrm{Ca}^{2+}$ transients in response to 40 synaptic or 40 TGU stimulations was similar between $D f(16) 1 /+$ and WT mice. Rise times (10-90\%) of Fluo $5 \mathrm{~F}$ fluorescence changes were $134.4 \pm 6.6 \mathrm{~ms}$ in $\mathrm{Df1}(16) 1 /+$ mice and $136.9 \pm 12.0 \mathrm{~ms}$ in WT mice (12-15 neurons) in response to synaptic stimulation and $168.4 \pm 13.9$ and $153.4 \pm 4.2 \mathrm{~ms}(7-11$ neurons), respectively, in response to TGU ( $p=0.139$, one-way ANOVA). Decay times (90-10\%) were $857.4 \pm 60.1 \mathrm{~ms}$ in $D f(16) 1 /+$ mice and $758.3 \pm 62.0 \mathrm{~ms}$ in WT mice during synaptic stimulation (12-15 neurons) and $907.3 \pm 125.1$ and $895.4 \pm$ $104.5 \mathrm{~ms}$ (7-11 neurons), respectively, during TGU ( $p=0.790$, 
a

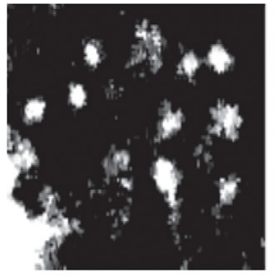

b

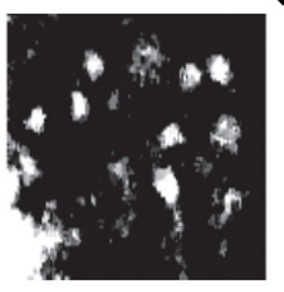

C
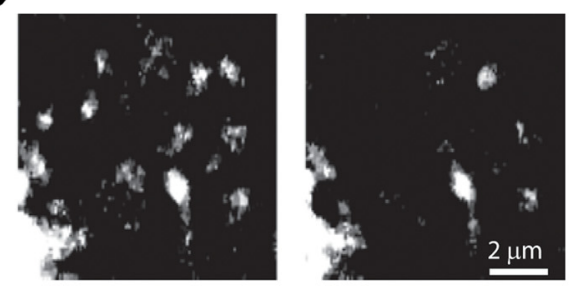

d

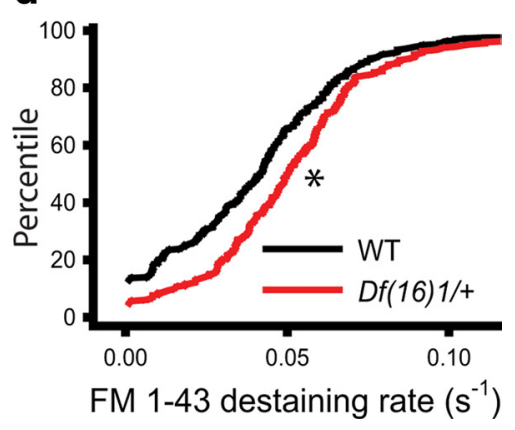

Figure 4. Neurotransmitter release is enhanced in mature $D f(16) 1 /+$ mice. $a$, Representative images of presynaptic boutons loaded with the fluorescent dye FM 1-43 before or after synaptic stimulation (arrow). $\boldsymbol{b}$, Examples of destaining curves for 16 boutons before and after 10 trains of synaptic stimulation (arrows). Each arrow represents 40 stimulations at $200 \mathrm{~Hz}$. $\boldsymbol{c}$, Average FM $1-43$ destaining curves for boutons in slices from WT and Df(16)1/+ littermates (7 slices per genotype, $17-67$ boutons per slice; ${ }^{*} p<0.05$ ). $\boldsymbol{d}$, Cumulative histograms of rates of FM 1-43 destaining in boutons from WT or Df(16)1/+ mice $\left(242-265\right.$ boutons; $\left.{ }^{*} p<0.01\right)$.

one-way ANOVA). EPSPs evoked by $200 \mathrm{~Hz}$ TGU in these experiments were also similar between genotypes $(p=0.765 ; 7-11$ neurons) (data not shown). Similarly, in voltage-clamp experiments, $40 \mathrm{TGU}$ stimulations delivered at $200 \mathrm{~Hz}$ to dendritic spines evoked EPSCs of similar amplitudes $(p=0.257$; five to six neurons) in $D f(16) 1 /+$ and WT mice (Fig. 3i). In a similar fashion, no differences in amplitudes or kinetics of postsynaptic $\mathrm{Ca}^{2+}$ transients were detected between genotypes in response to a single TGU stimulation (supplemental Fig. S5, available at www. jneurosci.org as supplemental material). Because we detected no difference in calcium transients between genotypes in TGU experiments, we tested whether glutamatergic receptors and the calcium indicator were saturated during these experiments. Longer TGU stimulations ( 80 or 120 pulses) delivered at $200 \mathrm{~Hz}$ produced significantly larger calcium transients in dendritic spines than did 40 TGU stimulations ( $p<0.05 ; 10$ neurons). This result indicates that neither glutamatergic receptors nor the calcium indicator were saturated during our TGU experiments (supplemental Fig. S6, available at www.jneurosci.org as supplemental material). Together, these findings indicate that the $D f(16) 1$ microdeletion does not affect postsynaptic neurons but enhances neurotransmitter release from presynaptic terminals during high-frequency synaptic activity.

\section{Neurotransmitter release during tetanic stimulation is increased in mature $D f 16(1) /+$ mice}

Because previous experiments suggested involvement of enhanced neurotransmitter release in the LTP phenotype in mature $D f(16) 1 /+$ mice during high-frequency activity, we decided to test this hypothesis using a more direct method. For this purpose, we compared neurotransmitter release in individual presynaptic boutons by using the FM 1-43 dye-unloading assay in acute hippocampal slices. We have previously shown that this assay can reliably measure the rate of neurotransmitter release from presynaptic terminals (Zakharenko et al., 2001, 2002). We labeled presynaptic CA3 terminals by electrically stimulating Schaffer collaterals at $10 \mathrm{~Hz}$ in the presence of the NMDA receptor blocker D-APV $(50 \mu \mathrm{M})$ and the fluorescent dye FM 1-43 (10 $\mu \mathrm{M})$. After washing out the extracellular dye, we observed fluorescent puncta representing stimulated presynaptic boutons (Fig. 4a). A subsequent synaptic stimulation mimicking the LTP induction protocol and delivered as 10 trains of 40 stimulations at $200 \mathrm{~Hz}$, unloaded the dye from these presynaptic boutons (Fig. 4b). FM 1-43 destaining from each fluorescent punctum was fitted with a single exponential decay, and destaining rates were calculated. We found that the average rate of FM 1-43 destaining, which was measured as the reciprocal value of FM 1-43 destaining half-times $\left(1 / t_{1 / 2}\right)$, was faster for boutons from $D f(16) 1 /+$ mice $\left(0.0562 \pm 0.0022 \mathrm{~s}^{-1}\right)$ than for boutons of WT mice $\left(0.0481 \pm 0.0019 \mathrm{~s}^{-1} ; n=7\right.$ slices for both genotypes, $17-67$ boutons per slice; $p=0.019$ ) (Fig. $4 c, d$ ). These results confirm that evoked neurotransmitter release, rather than postsynaptic function, is enhanced in the $D f(16) 1 /+$ mouse model of 22q11DS.

Presynaptic calcium dynamics and SERCA2 levels are altered in mature $D f(16) /+$ mice

Evoked neurotransmitter release depends on the concentration of $\mathrm{Ca}^{2+}$ inside presynaptic terminals. To test whether presynaptic $\mathrm{Ca}^{2+}$ is responsible for the observed augmentation of neurotransmitter release, we measured $\mathrm{Ca}^{2+}$ transients in presynaptic terminals of CA3 pyramidal neurons from mature $D f(16) 1 /+$ and WT mice (Fig. 5). Cells were filled with Alexa 594 and Fluo $5 \mathrm{~F}$, and presynaptic boutons were identified along axons. Axons were distinguished from dendrites by their thinner diameter and the lack of dendritic spines (Fig. 5a). Calcium transients were detected in individual boutons in response to an AP triggered by injecting a step of depolarizing current through a whole-cell pipette. We found that a single AP triggered $\mathrm{Ca}^{2+}$ transients of similar amplitudes in presynaptic boutons of mature $D f(16) 1 /+$ 
and WT mice $(p=0.66 ; 34-36$ boutons from 10-12 neurons) (Fig. 5b). Rise times (10-90\%) of $\mathrm{Ca}^{2+}$ transients were also indistinguishable between presynaptic boutons of mutant $(2.35 \pm 0.18 \mathrm{~ms} ; n=$ $34)$ and WT mice ( $2.41 \pm 0.15 \mathrm{~ms} ; n=36$; $p=0.78)$. However, decays of $\mathrm{Ca}^{2+}$ transients $(90-10 \%)$ were somewhat slower in boutons of $D f(16) 1 /+$ mice (114.26 \pm $15.07 \mathrm{~ms} ; n=34$ ) than in WT littermates (73.22 $\pm 7.34 \mathrm{~ms} ; n=36 ; p=0.036)$. This modest alteration in presynaptic $\mathrm{Ca}^{2+} \mathrm{ki}-$ netics was substantially exacerbated when we evoked $\mathrm{Ca}^{2+}$ transients with the LTP induction protocol (40 APs delivered at $200 \mathrm{~Hz}$ ) (Fig. $5 c$ ). Similar to the single-AP experiment, the rise of $\mathrm{Ca}^{2+}$ transients showed no detectable difference between the genotypes [rise times (10-90\%), $91.6 \pm 2.9$ and $91.5 \pm 2.3 \mathrm{~ms}$, respectively; $p=0.79$; 40 boutons/15 neurons per genotype]. However, the decays $(90-10 \%)$ of $\mathrm{Ca}^{2+}$ transients evoked by 40 APs were significantly slower in boutons of mature $D f(16) 1 /+$ mice $(1491.2 \pm 117.5 \mathrm{~ms} ; n=$ 40) than in WT mice $(886.1 \pm 91.8 \mathrm{~ms}$; $n=40$; $p<0.001$ ) (Fig. $5 d$ ). The amplitude of $\mathrm{Ca}^{2+}$ transients evoked by the LTP induction protocol was also increased in $D f(16) 1 /+$ mice. Peak amplitude of Fluo $5 \mathrm{~F}$ fluorescence evoked by 40 APs in presynaptic terminals of CA3 neurons was $\sim 30 \%$ higher in $D f(16) 1 /+$ mice than in WT littermates $(p<0.001 ; n=40$ per genotype). These data indicate a strong dysregulation of $\mathrm{Ca}^{2+}$ dynamics in presynaptic terminals of $D f(16) 1 /+$ mutants.

The AP-evoked rise in $\mathrm{Ca}^{2+}$ concentration in presynaptic terminals occurs via activation of voltage-gated $\mathrm{Ca}^{2+}$ channels and is augmented through the release of $\mathrm{Ca}^{2+}$ from internal stores (Emptage et al., 2001). The observations that EPSCs evoked by a single synaptic stimulation (Fig. 1e) and that rise times of presynaptic $\mathrm{Ca}^{2+}$ transients are normal in $D f(16) 1 /+$ mice strongly argue against the notion that $\mathrm{Ca}^{2+}$ influx through voltage-gated $\mathrm{Ca}^{2+}$ channels is affected in these mutants. Therefore, we focused our attention on internal $\mathrm{Ca}^{2+}$ stores, which are filled primarily through SERCA-mediated mechanisms. To test whether the level of SERCA is altered in $D f(16) 1 /+$ mice, we used Western blotting of hippocampal extracts to compare protein levels of SERCA2, the only SERCA isoform expressed in the forebrain (Baba-Aissa et al., 1998).

Quantification of Western blots revealed that the level of SERCA2 protein was increased $\sim 20 \%$ in whole-tissue lysates of mutant hippocampus compared with that of WT littermates ( $p=$ 0.006; nine mice per genotype) (Fig. $6 b, c)$. This difference was not observed in younger mice ( $p=0.84 ; 8-10$ mice) (Fig. 6a,c), indicating that a dysregulation of SERCA expression occurs with an age dependence similar to that of the LTP and spatial memory phenotypes. SERCA2 transcript levels, measured by quantitative real-time PCR, were unaltered (supplemental Fig. S7, available at www.jneurosci.org as supplemental material), indicating that dysregulation of SERCA2 occurs only at the protein level. This is consistent with results from microarray studies of 22q11DS mod-

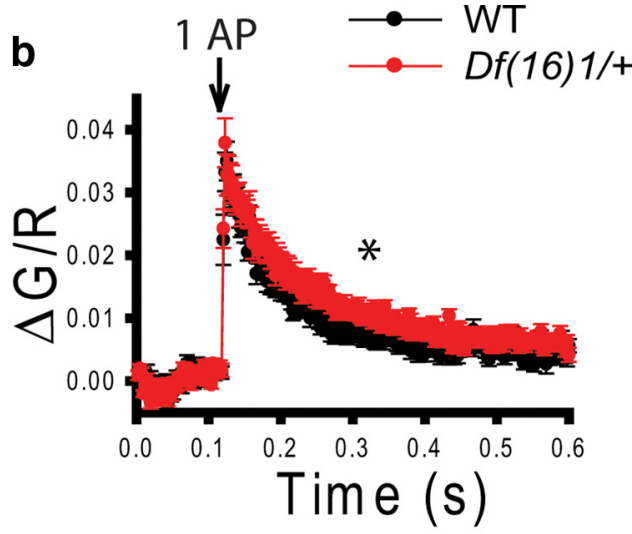

d

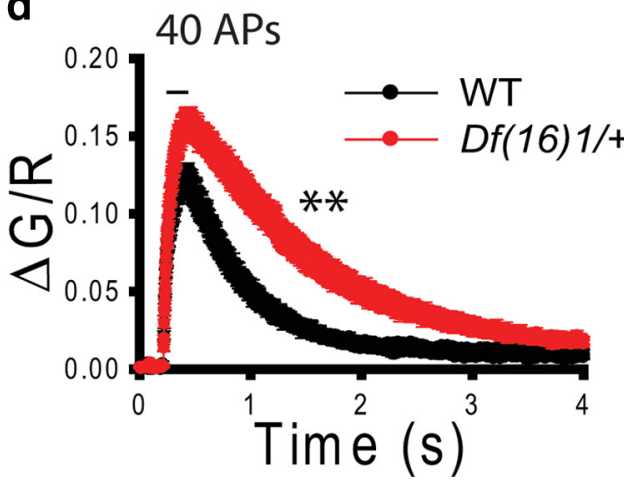

Figure 5. Presynaptic calcium dynamics are altered in mature $D f(16) 1 /+$ mice. $\boldsymbol{a}$, Image of an axon of a CA3 pyramidal neuron. and mutant mice. $\boldsymbol{d}$, Averaged normalized Flu05F fluorescence measured in presynaptic boutons before and after generating 40 APs in presynaptic neurons of mature $D f(16) 1 /+$ mice and WT mice ( ${ }^{* *}$ decay times, $\left.p<0.001\right)$.

els, which have shown no alterations in SERCA2 transcript levels (Prescott et al., 2005; Jurata et al., 2006; Stark et al., 2008). Because mature $D f(16) 1 /+$ mice show an enhancement in synaptic plasticity, we tested whether the level of SERCA2 is increased in the synapses of these mutants. The level of SERCA2 protein was significantly higher in hippocampal synaptosomes of mature $D f(16) 1 /+$ mice than in synaptosomes from WT littermates $(p<$ $0.001 ; 8-10$ mice) (Fig. $6 d-f)$.

\section{SERCA2 inhibitors rescue synaptic phenotypes in mature Df16(1)/+ mice}

To test whether SERCA influenced the enhanced neurotransmitter release and LTP in mature $D f(16) 1 /+$ mice, we first measured the rates of FM 1-43 destaining in the presence of CPA $(50 \mu \mathrm{M})$, an inhibitor of SERCA pumps that depletes internal $\mathrm{Ca}^{2+}$ stores. The addition of CPA eliminated the difference in FM 1-43 destaining between mature $D f(16) 1 /+$ and WT mice (Fig. $7 a$ ). In the presence of CPA, the rate of FM 1-43 destaining in $D f(16) 1 /+$ mice elicited with $200 \mathrm{~Hz}$ tetanus trains reached $0.0467 \pm 0.0026$ $\mathrm{s}^{-1}$ ( $n=10$ slices, $21-84$ boutons per slice), which was significantly slower than that in the absence of CPA $(p=0.02$; seven slices). In contrast, in WT mice the rates of FM 1-43 destaining were similar in the presence $\left(0.0479 \pm 0.0027 \mathrm{~s}^{-1} ; n=8\right.$ slices, $13-46$ boutons per slice) or absence $(n=7 ; p=0.96)$ of CPA (Fig. $7 b$ ). Interestingly, in the presence of CPA, the rates of FM 1-43 destaining from presynaptic boutons in $D f(16) 1 /+$ and WT mice did not differ $(p=0.76)$; thus, CPA rescued enhanced neurotransmitter release in $D f(16) 1 /+$ mice. We also found no sig- 
a

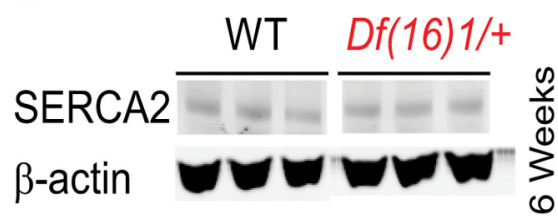

b

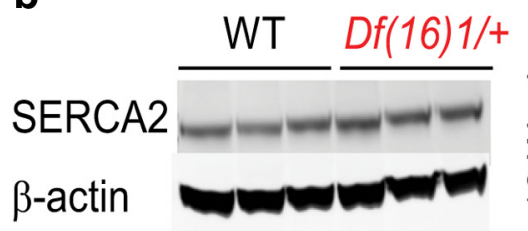

C

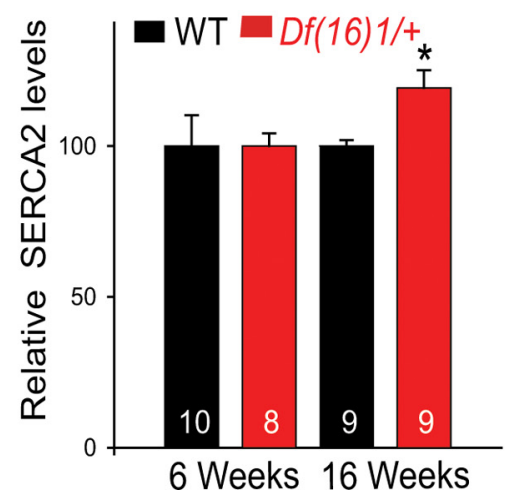

d
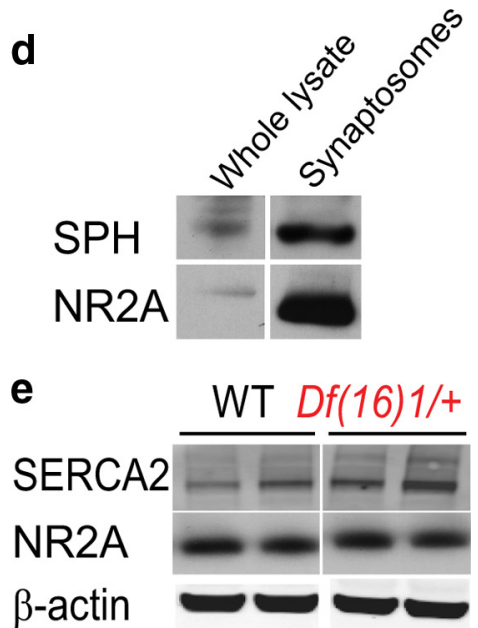

f

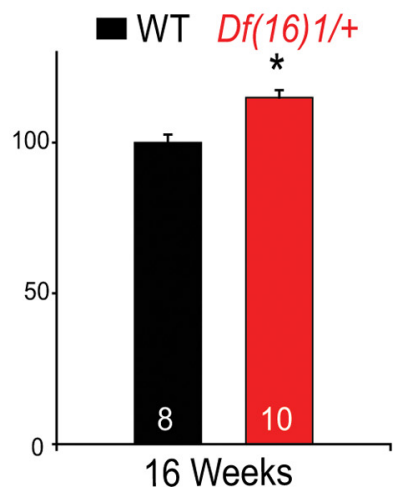

Figure 6. The level of SERCA2 protein is elevated in the hippocampus of mature but not young $D f(16) 1 /+$ mice. $\boldsymbol{a}, \boldsymbol{b}$, Representative Western blots of hippocampal extracts from WT and Df(16)1/+ littermates aged 6 weeks $(\boldsymbol{a})$ or 16 weeks $(\boldsymbol{b})$. The $\beta$-actin (control) signal is within detection range of the 0dyssey imager. $c$, Average relative hippocampal protein levels of SERCA2 in young and mature WT and Df(16)1/+ mice normalized to $\beta$-actin levels. $\boldsymbol{d}$, Western blot showing the enrichment of the presynaptic protein synaptophysin (SPH) and the postsynaptic NMDA receptor NR2A in crude synaptosomal preparations from hippocampus. $\boldsymbol{e}, \boldsymbol{f}$, Representative lanes from Western blots $(\boldsymbol{e})$ and quantification of SERCA2 levels in synaptosomal preparations from WT and Df(16)1/+ hippocampus $(\boldsymbol{f}){ }^{*} p<0.01$.

nificant difference in decay $(p=0.22)$ or amplitude $(p=0.72)$ of presynaptic $\mathrm{Ca}^{2+}$ transients evoked by $40 \mathrm{APs}(200 \mathrm{~Hz})$ in the presence of CPA in WT and $D f(16) 1 /+$ mice (14-19 boutons, five neurons per genotype) (Fig. $7 c, d)$. These data indicate that blocking SERCA with CPA rescued presynaptic calcium dysregulation in mutant mice. In a similar fashion, CPA rescued the increase in PPF in $D f(16) 1 /+$ mice. Thus, PPF measured at 20 and $50 \mathrm{~ms}$ intervals in $D f(16) 1 /+$ mice was significantly reduced from $2.09 \pm 0.15$ and $2.01 \pm 0.09$, respectively, in the absence of CPA to $1.78 \pm 0.13(p=0.001 ; 28$ slices $)$ and $1.76 \pm 0.09(p=$ 0.019 ; 28 slices) when CPA was added to the bath solution. In contrast, in WT mice PPF was similar in the presence $(1.64 \pm 0.11$ for $20 \mathrm{~ms}$ and $1.61 \pm 0.05$ for $50 \mathrm{~ms}$ intervals; 19 slices) and in the absence of CPA $(1.58 \pm 0.08$ for $20 \mathrm{~ms} ; p=0.49$ and $1.69 \pm 0.05$ for $50 \mathrm{~ms}$ intervals; $p=0.62 ; 19$ slices). Importantly, no significant difference in PPF was found between the genotypes in the presence of CPA ( $p=0.283$ for $20 \mathrm{~ms}$ interval and $p=0.455$ for the $50 \mathrm{~ms}$ interval; $19-28$ slices). Together, these data indicate that the depletion of internal $\mathrm{Ca}^{2+}$ stores rescued the enhancement of presynaptic $\mathrm{Ca}^{2+}$ transients and neurotransmitter release in mature $D f(16) 1 /+$ mice. They also predict that the depletion of $\mathrm{Ca}^{2+}$ stores by SERCA inhibitors should rescue the LTP enhancement in mature $D f(16) 1 /+$ mice.

To test this prediction, we measured LTP induced by $200 \mathrm{~Hz}$ tetanization in the presence of either CPA or thapsigargin (4 $\mu \mathrm{M})$, another SERCA inhibitor. Both agents rescued the enhancement of PTP and LTP in $D f(16) 1 /+$ mice. In CPAtreated slices from $D f(16) 1 /+$ mice, fEPSP $_{5}$ was reduced to $45 \%(p<0.001)$, and $\mathrm{fEPSP}_{360}$ was reduced to $60 \%$ of that detected in vehicle-treated $D f(16) 1 /+$ mice $(p=0.021 ; 16-23$ slices, seven to eight mice) (Fig. $7 e-h)$. Similarly, thapsigargin reduced the fEPSP $_{5}$ and fEPSP $_{360}$ in slices from $D f(16) 1 /+$ mice to $69 \%(p=$ $0.015)$ and $57 \%(p=0.005)$, respectively, of that in vehicle-treated $D f(16) 1 /+$ slices (22-23 slices; 8-10 mice). Interestingly, neither SERCA inhibitor affected WT LTP induced by the $200 \mathrm{~Hz}$ induction protocol. This is consistent with previous results that showed that SERCA inhibitors affect LTP induced only by weak [but not strong (e.g., $200 \mathrm{~Hz}$ )] stimulation protocols (Behnisch and Reymann, 1995; Matias et al., 2002; Zhang et al., 2009). Thus, in the presence of CPA, WT fEPSP $_{5}(p=$ $0.210)$ and $\operatorname{fEPSP}_{360}(p=0.680)$ were not significantly different from those seen in the absence of CPA (16-52 slices; 6-15 mice). Similarly, no significant difference was seen between $\mathrm{fEPSP}_{5}(p=0.384)$ and fEPSP $_{360}(p=0.939)$ in the presence or absence of thapsigargin (22-52 slices; 10-15 mice). Importantly, in the presence of CPA and thapsigargin, the increases in fEPSPs at either time point were not significantly different between mature $D f(16) 1 /+$ and WT mice $(p=0.951$ and $p=0.436$ for $\mathrm{fEPSP}_{5}$, and $p=0.297$ and $p=0.623$ for $\mathrm{fEPSP}_{360}$, respectively), indicating that inhibition of SERCA rescued the LTP phenotype in $D f(16) 1 /+$ mice (Fig. $7 e-h)$.

\section{Discussion}

Here, we report three major findings relevant to the mechanisms of cognitive deficits in 22q11DS. First, we showed that, within 16-20 weeks of birth, the $D f(16) 1 /+$ mouse model of 22q11DS develops a substantial enhancement in LTP that coincides with a deficit in spatial memory. Second, the increase in LTP caused by the hemizygous deletion of 22q11DS-related genes is attributable to enhanced glutamate release from presynaptic terminals and not attributable to changes in postsynaptic structures or function. Third, we pinpointed SERCA2 upregulation as a contributor to the dysregulation of presynaptic $\mathrm{Ca}^{2+}$, enhanced glutamate release, and increased LTP in our model of 22q11DS.

Multiple studies have linked 22q11DS with schizophrenia (Pulver et al., 1994; Gothelf et al., 1997; Yan et al., 1998; Bassett and Chow, 1999; Murphy et al., 1999; Ivanov et al., 2003; Karayiorgou and Gogos, 2004; Horowitz et al., 2005). These findings represent one of the strongest links to date between schizophrenia susceptibility and a known genetic anomaly such as 22q11 microdeletion (Kirov et al., 2005). Cognitive impairment has been regarded as a hallmark feature of schizophrenia (Elvevåg 

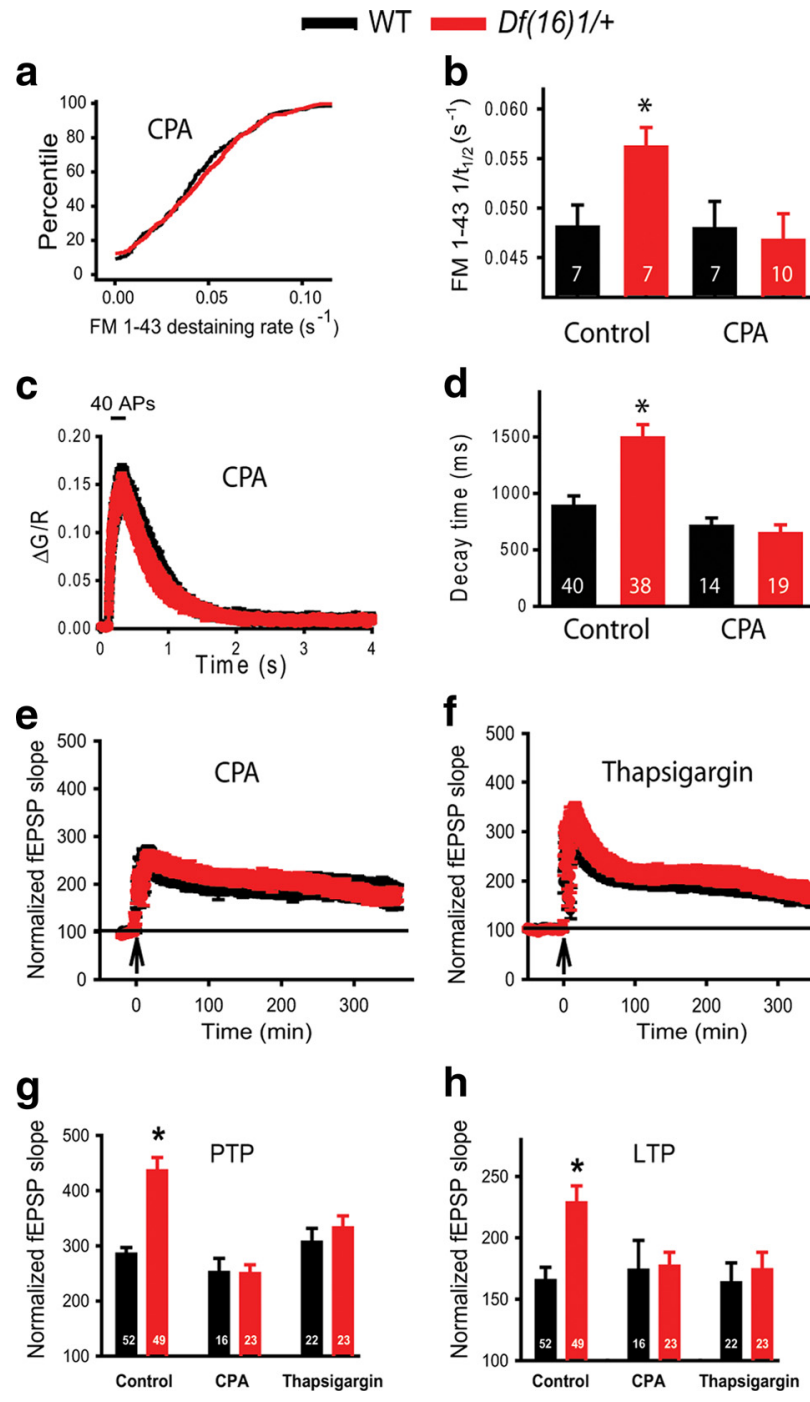

Figure 7. Inhibition of SERCA rescues enhanced presynaptic function and LTP in mature Df(16)1/+ mice. $\boldsymbol{a}$, Cumulative rates of FM 1-43 destaining in individual boutons during 10 trains of $200 \mathrm{~Hz}$ tetanus (40 APs) in slices from Df(16)1/+ and WT mice in the presence of CPA (205- 469 boutons). $\boldsymbol{b}$, Mean FM 1-43 destaining rates during 10 trains of $200 \mathrm{~Hz}$ tetanus in presynaptic boutons of Df(16)1/+ and WT littermates in the presence or absence of CPA. C, Average calcium transients during $200 \mathrm{~Hz}$ tetanus (40 APs) in presynaptic boutons of Df(16) $1 /+$ and WT littermates in the presence of CPA. $\boldsymbol{d}$, Mean calcium transient decay times $(90-10 \%)$ in response to $200 \mathrm{~Hz}$ tetanus in presynaptic boutons of Df(16)1/+ and WT littermates in the presence or absence of CPA. $\boldsymbol{e}, \boldsymbol{f}$, Field EPSPs as a function of time in slices from $D f(16) 1 /+$ and WT mice in the presence of CPA $(\boldsymbol{e})$ or thapsigargin $(\boldsymbol{f})$. Mean $\mathrm{fEPSP}_{5}(\boldsymbol{g})$ and mean fEPSP ${ }_{360}(\boldsymbol{h})$ in slices of $D f(16) 1 /+$ and WT mice in the absence (control) or presence of CPA or thapsigargin. ${ }^{*} p<0.05$.

and Goldberg, 2000) and 22q11DS (Eliez et al., 2000; Swillen et al., 2000; Bearden et al., 2001). In our study, we used hippocampal LTP as a model for cellular mechanisms of cognitive function. The onset of enhanced LTP coincided with the spatial memory deficit in mature mutant mice. This may seem counterintuitive, because LTP is thought to be a cellular correlate of learning and memory (Milner et al., 1998; Martin et al., 2000; Whitlock et al., 2006). Indeed, some mutants that show increased LTP also show a concomitant increase in water maze performance (Malleret et al., 2001; Chen et al., 2003). However, the $D f(16) 1$ deletion joins a growing list of mutations that result in enhancement of LTP but impairment of performance in spatial memory tasks (Migaud et al., 1998; Uetani et al., 2000; Kaksonen et al., 2002; Rutten et al.,
2008; Kim et al., 2009). This trend suggests that plasticity within a certain range is beneficial for cognition, whereas abnormal weakening or strengthening of synapses is equally disadvantageous to learning and memory (Migaud et al., 1998).

Modeling of cognitive phenotypes in mouse models of psychiatric disease remains a challenging task. Most studies that attempt this rely on tests that can detect mild to moderate changes in measurable behaviors. In our study, a deficit in spatial memory was accompanied by a dramatic, severalfold increase in LTP in mature $D f 1(16) 1 /+$ mice. This robust phenotype can further be used to dissect biological processes underlying the cognitive features of 22q11DS.

The increase in LTP in Df1(16)1/+ mice could be a consequence of structural changes in the hippocampus. Previous studies have reported structural abnormalities in pyramidal neurons in the hippocampus of young (8 week) 22q11DS mouse models (Mukai et al., 2008; Stark et al., 2008). We were not able to reproduce the decreases in dendritic complexity and spine density that were observed in those studies. Although the aforementioned studies used a different mouse carrying a larger deletion, all candidate genes (e.g., Dgcr8 and $Z d h h c 8)$ to which structural abnormalities were attributed are also deleted in the $D f(16) 1 /+$ mouse. Therefore, haploinsufficiency of genes outside the $D f(16) 1$ deletion could be responsible for structural changes seen in other studies. Similarly, the minor abnormality in synaptic vesicle diameter observed in our study was insufficient to affect basal synaptic transmission and cannot explain the observed LTP enhancement. Therefore, we conclude that functional, rather than morphological, changes underlie the hippocampal dysfunction observed in this mouse model of 22q11DS.

By measuring the rates of FM 1-43 destaining as a direct indicator of neurotransmitter release, comparing $\mathrm{Ca}^{2+}$ transients and EPCSs evoked by synaptic stimulation and TGU, and conducting electrophysiological analyses of short-term synaptic plasticity, we identified presynaptic terminals as the cellular locus of changes in LTP in mature $D f(16) 1 /+$ mice. Our imaging, molecular, and pharmacological experiments show that presynaptic internal $\mathrm{Ca}^{2+}$ stores are responsible for this effect. We detected that the level of SERCA2 protein is increased by $15-20 \%$ in the hippocampus of $D f(16) 1 /+$ mice. Because of the highly cooperative relationship between presynaptic $\mathrm{Ca}^{2+}$ and neurotransmitter release processes (Mintz et al., 1995; Borst and Sakmann, 1996), it is feasible that even slight perturbations in the presynaptic $\mathrm{Ca}^{2+}$ store machinery can profoundly affect presynaptic $\mathrm{Ca}^{2+}$ dynamics and neurotransmitter release. Indeed, $\mathrm{Ca}^{2+} \mathrm{dy}-$ namics in $D f(16) 1 /+$ presynaptic terminals were substantially altered in response to tetanization, and this had a profound effect on neurotransmitter release. SERCA inhibitors reliably rescued altered $\mathrm{Ca}^{2+}$ dynamics and neurotransmitter release, indicating that the increase in SERCA level affects the function of presynaptic terminals of $D f(16) 1 /+$ mice. SERCA inhibitors also rescued the LTP phenotype in $D f(16) 1 /+$ mice, indicating that $\mathrm{Ca}^{2+}$ dysregulation in presynaptic terminals contributes to hippocampal dysfunction in this model of 22q11DS. It has been reported that SERCAs are also involved in $\mathrm{Ca}^{2+}$-extrusion mechanisms in postsynaptic dendritic spines (Emptage et al., 1999; Majewska et al., 2000). However, given that the postsynaptic characteristics of $D f(16) 1 /+$ and WT mice are similar and SERCA inhibitors were ineffective at reducing LTP in mature WT mice, it is unlikely that these postsynaptic effects of SERCA inhibitors contribute to their rescue of presynaptic phenotypes and enhanced LTP in $D f(16) 1 /+$ mice. 
$\mathrm{Ca}^{2+}$ dysregulation has been implicated in several disorders that affect cognitive function. For instance, a role for $\mathrm{Ca}^{2+}$ dysregulation in Alzheimer disease is currently under scrutiny. Recent works have shown that presenilins interact with SERCA (Green et al., 2008) and that mice lacking presenilins exhibit decreased $\mathrm{Ca}^{2+}$ storage and release from the endoplasmic reticulum (ER) of presynaptic terminals. This presenilin-mediated alteration of $\mathrm{Ca}^{2+}$ dynamics leads to reduced neurotransmitter release and reduced LTP at CA3-CA1 synapses (Zhang et al., 2009). Upregulation of SERCA2 in $D f(16) 1 /+$ mice may produce the opposite effect, increasing presynaptic ER $\mathrm{Ca}^{2+}$ concentration, and thus abnormally increasing $\mathrm{Ca}^{2+}$-dependent neurotransmitter release on high-frequency hippocampal activity.

The observed slower decays of $\mathrm{Ca}^{2+}$ transients in presynaptic terminals of $D f(16) 1 /+$ mutants is a feature of $\mathrm{Ca}^{2+}$ dysregulation inside presynaptic terminals. The exact mechanisms of slower $\mathrm{Ca}^{2+}$ decays are unclear, but their rescue by SERCA inhibitors implies a higher $\mathrm{Ca}^{2+}$ level in the ER of $D f(16) 1 /+$ mutants and therefore a higher gradient that $\mathrm{Ca}^{2+}$ entering the ER must overcome. The application of SERCA inhibitors depletes $\mathrm{Ca}^{2+}$ stores and presumably eliminates the differences seen in $\mathrm{Ca}^{2+}$ store levels of WT and $D f(16) 1 /+$ mice. This notion is consistent with our results that, in the presence of CPA, decay times of $\mathrm{Ca}^{2+}$ transients are similar in $D f(16) 1 /+$ and WT mice. Prolonged $\mathrm{Ca}^{2+}$ decays in presynaptic terminals of mutant mice may also be a reflection of the enhanced $\mathrm{Ca}^{2+}$-induced release of $\mathrm{Ca}^{2+}$ that is enacted during prolonged presynaptic stimulation (Unni et al., 2004).

Slower decay of presynaptic $\mathrm{Ca}^{2+}$ transients may explain the enhanced paired-pulse ratio observed in $D f(16) 1 /+$ mice. The paired-pulse ratio has classically been used as an inverse measure of the probability of neurotransmitter release, with an increase in this ratio often reflecting a decrease in the probability of release during the first pulse. However, this is not the case in $D f(16) 1 /+$ mice, because synaptic transmission evoked by a single synaptic stimulation is normal. Instead, the increased paired-pulse ratio most likely reflects the slower $\mathrm{Ca}^{2+}$ decay rate during the first pulse resulting in greater $\mathrm{Ca}^{2+}$-induced neurotransmitter release during the second pulse. This phenomenon would intensify with high frequencies that are used for induction of STP or LTP. Highfrequency stimulation reduces the time allowed for delayed $\mathrm{Ca}^{2+}$ clearance in mutant mice and, therefore, magnifies synaptic facilitation.

We linked the presynaptic phenotypes uncovered in $D f(16) 1 /+$ mice to the upregulation of SERCA2. Mammals express several SERCA pump isoforms encoded by three genes. The ubiquitously expressed SERCA2 gene is the only one expressed in forebrain neurons (Baba-Aissa et al., 1998). Human genetics studies have indicated that mutations in SERCA2 cause Darier disease, a dermatologic condition that is comorbid with various neuropsychiatric abnormalities including epilepsy, bipolarspectrum mood disorders, and schizophrenia (Jacobsen et al., 1999; Ruiz-Perez et al., 1999). Our data show that the upregulation of SERCA2 at excitatory synapses may contribute to the cognitive symptoms of 22q11DS and suggest a general role for this protein as a predictor of cognitive symptoms.

Identification of the gene(s) within the deletion region that affect SERCA2 levels and synaptic plasticity in an age-dependent manner is the focus of ongoing research. Although a systematic approach is required to identify the culprit gene(s) within the deletion, several candidate genes have been implicated in 22q11DS pathology, primarily through behavioral assays. Gnb1L and the transcription factor $T b \times 1$ have been implicated in senso- rimotor gating deficits displayed by $D f(16) 1 /+$ mice (Paylor et al., 2006). Mice with a deletion of $D g c r 8$, a gene that encodes a microRNA-processing protein, have also shown sensorimotor gating and cognitive deficits (Stark et al., 2008). Genes encoding the enzymes proline dehydrogenase (Prodh) and catechol-Omethyltransferase (Comt), which regulate the levels of the neuromodulators L-proline and dopamine, respectively, are also contained in the 22q11-deletion region. Prodh-mutant mice exhibit cognitive and sensorimotor abnormalities and upregulation of the Comt transcript (Paterlini et al., 2005); thus, these genes are candidates for contributors to the cognitive decline reported herein. Additional studies using mutant mice carrying smaller deletions (Paylor and Lindsay, 2006) and mutations of single genes within the $D f(16) 1$ microdeletion will determine which gene(s) are responsible for upregulation of SERCA2, enhanced LTP, and cognitive deficits in 22q11DS.

\section{References}

Baba-Aissa F, Raeymaekers L, Wuytack F, Dode L, Casteels R (1998) Distribution and isoform diversity of the organellar $\mathrm{Ca}^{2+}$ pumps in the brain. Mol Chem Neuropathol 33:199-208.

Bassett AS, Chow EW (1999) 22q11 deletion syndrome: a genetic subtype of schizophrenia. Biol Psychiatry 46:882-891.

Bayazitov IT, Richardson RJ, Fricke RG, Zakharenko SS (2007) Slow presynaptic and fast postsynaptic components of compound long-term potentiation. J Neurosci 27:11510-11521.

Bearden CE, Woodin MF, Wang PP, Moss E, McDonald-McGinn D, Zackai E, Emannuel B, Cannon TD (2001) The neurocognitive phenotype of the 22q11.2 deletion syndrome: selective deficit in visual-spatial memory. J Clin Exp Neuropsychol 23:447-464.

Behnisch T, Reymann KG (1995) Thapsigargin blocks long-term potentiation induced by weak, but not strong tetanisation in rat hippocampal CA1 neurons. Neurosci Lett 192:185-188.

Bloodgood BL, Sabatini BL (2005) Neuronal activity regulates diffusion across the neck of dendritic spines. Science 310:866-869.

Borst JG, Sakmann B (1996) Calcium influx and transmitter release in a fast CNS synapse. Nature 383:431-434.

Cavus I, Teyler T (1996) Two forms of long-term potentiation in area CA1 activate different signal transduction cascades. J Neurophysiol 76:3038-3047

Chen A, Muzzio IA, Malleret G, Bartsch D, Verbitsky M, Pavlidis P, Yonan AL, Vronskaya S, Grody MB, Cepeda I, Gilliam TC, Kandel ER (2003) Inducible enhancement of memory storage and synaptic plasticity in transgenic mice expressing an inhibitor of ATF4 (CREB-2) and C/EBP proteins. Neuron 39:655-669.

Chow EW, Zipursky RB, Mikulis DJ, Bassett AS (2002) Structural brain abnormalities in patients with schizophrenia and 22q11 deletion syndrome. Biol Psychiatry 51:208-215.

Chow EW, Watson M, Young DA, Bassett AS (2006) Neurocognitive profile in $22 \mathrm{q} 11$ deletion syndrome and schizophrenia. Schizophr Res $87: 270-278$.

Debbané M, Schaer M, Farhoumand R, Glaser B, Eliez S (2006) Hippocampal volume reduction in 22q11.2 deletion syndrome. Neuropsychologia 44:2360-2365.

Deboer T, Wu Z, Lee A, Simon TJ (2007) Hippocampal volume reduction in children with chromosome 22q11.2 deletion syndrome is associated with cognitive impairment. Behav Brain Funct 3:54.

Eliez S, Palacio-Espasa F, Spira A, Lacroix M, Pont C, Luthi F, Robert-Tissot C, Feinstein C, Schorderet DF, Antonarakis SE, Cramer B (2000) Young children with velo-cardio-facial syndrome (CATCH-22). Psychological and language phenotypes. Eur Child Adolesc Psychiatry 9:109-114.

Eliez S, Blasey CM, Schmitt EJ, White CD, Hu D, Reiss AL (2001) Velocardiofacial syndrome: are structural changes in the temporal and mesial temporal regions related to schizophrenia? Am J Psychiatry 158:447-453.

Elvevåg B, Goldberg TE (2000) Cognitive impairment in schizophrenia is the core of the disorder. Crit Rev Neurobiol 14:1-21.

Emptage N, Bliss TV, Fine A (1999) Single synaptic events evoke NMDA receptor-mediated release of calcium from internal stores in hippocampal dendritic spines. Neuron 22:115-124.

Emptage NJ, Reid CA, Fine A (2001) Calcium stores in hippocampal synap- 
tic boutons mediate short-term plasticity, store-operated $\mathrm{Ca}^{2+}$ entry, and spontaneous transmitter release. Neuron 29:197-208.

Gothelf D, Frisch A, Munitz H, Rockah R, Aviram A, Mozes T, Birger M, Weizman A, Frydman M (1997) Velocardiofacial manifestations and microdeletions in schizophrenic inpatients. Am J Med Genet 72:455-461.

Gothelf D, Penniman L, Gu E, Eliez S, Reiss AL (2007) Developmental trajectories of brain structure in adolescents with 22q11.2 deletion syndrome: a longitudinal study. Schizophr Res 96:72-81.

Gray EG, Whittaker VP (1962) The isolation of nerve endings from brain: an electron-microscopic study of cell fragments derived by homogenization and centrifugation. J Anat 96:79-88.

Green KN, Demuro A, Akbari Y, Hitt BD, Smith IF, Parker I, LaFerla FM (2008) SERCA pump activity is physiologically regulated by presenilin and regulates amyloid beta production. J Cell Biol 181:1107-1116.

Horowitz A, Shifman S, Rivlin N, Pisanté A, Darvasi A (2005) A survey of the 22q11 microdeletion in a large cohort of schizophrenia patients. Schizophr Res 73:263-267.

Ivanov D, Kirov G, Norton N, Williams HJ, Williams NM, Nikolov I, Tzwetkova R, Stambolova SM, Murphy KC, Toncheva D, Thapar A, O’Donovan MC, Owen MJ (2003) Chromosome 22q11 deletions, velocardio-facial syndrome and early-onset psychosis. Molecular genetic study. Br J Psychiatry 183:409-413.

Jacobsen NJ, Lyons I, Hoogendoorn B, Burge S, Kwok PY, O’Donovan MC, Craddock N, Owen MJ (1999) ATP2A2 mutations in Darier's disease and their relationship to neuropsychiatric phenotypes. Hum Mol Genet 8:1631-1636.

Jurata LW, Gallagher P, Lemire AL, Charles V, Brockman JA, Illingworth EL, Altar CA (2006) Altered expression of hippocampal dentate granule neuron genes in a mouse model of human 22q11 deletion syndrome. Schizophr Res 88:251-259.

Kaksonen M, Pavlov I, Võikar V, Lauri SE, Hienola A, Riekki R, Lakso M, Taira T, Rauvala H (2002) Syndecan-3-deficient mice exhibit enhanced LTP and impaired hippocampus-dependent memory. Mol Cell Neurosci 21:158-172.

Karayiorgou M, Gogos JA (2004) The molecular genetics of the 22q11associated schizophrenia. Brain Res Mol Brain Res 132:95-104.

Kim JJ, Fanselow MS (1992) Modality-specific retrograde amnesia of fear. Science 256:675-677.

Kim MH, Choi J, Yang J, Chung W, Kim JH, Paik SK, Kim K, Han S, Won H, Bae YS, Cho SH, Seo J, Bae YC, Choi SY, Kim E (2009) Enhanced NMDA receptor-mediated synaptic transmission, enhanced long-term potentiation, and impaired learning and memory in mice lacking IRSp53. J Neurosci 29:1586-1595.

Kirov G, O’Donovan MC, Owen MJ (2005) Finding schizophrenia genes. J Clin Invest 115:1440-1448.

Lindsay EA, Botta A, Jurecic V, Carattini-Rivera S, Cheah YC, Rosenblatt HM, Bradley A, Baldini A (1999) Congenital heart disease in mice deficient for the DiGeorge syndrome region. Nature 401:379-383.

Majewska A, Brown E, Ross J, Yuste R (2000) Mechanisms of calcium decay kinetics in hippocampal spines: role of spine calcium pumps and calcium diffusion through the spine neck in biochemical compartmentalization. J Neurosci 20:1722-1734.

Malleret G, Haditsch U, Genoux D, Jones MW, Bliss TV, Vanhoose AM, Weitlauf C, Kandel ER, Winder DG, Mansuy IM (2001) Inducible and reversible enhancement of learning, memory, and long-term potentiation by genetic inhibition of calcineurin. Cell 104:675-686.

Martin SJ, Grimwood PD, Morris RG (2000) Synaptic plasticity and memory: an evaluation of the hypothesis. Annu Rev Neurosci 23:649-711.

Matias C, Dionísio JC, Quinta-Ferreira ME (2002) Thapsigargin blocks STP and LTP related calcium enhancements in hippocampal CA1 area. Neuroreport 13:2577-2580.

Matsuzaki M, Ellis-Davies GC, Nemoto T, Miyashita Y, Iino M, Kasai H (2001) Dendritic spine geometry is critical for AMPA receptor expression in hippocampal CA1 pyramidal neurons. Nat Neurosci 4:1086-1092.

Meechan DW, Tucker ES, Maynard TM, LaMantia AS (2009) Diminished dosage of 22q11 genes disrupts neurogenesis and cortical development in a mouse model of 22q11 deletion/DiGeorge syndrome. Proc Natl Acad Sci U S A 106:16434-16445.

Merscher S, Funke B, Epstein JA, Heyer J, Puech A, Lu MM, Xavier RJ, Demay MB, Russell RG, Factor S, Tokooya K, Jore BS, Lopez M, Pandita RK, Lia M, Carrion D, Xu H, Schorle H, Kobler JB, Scambler P, et al. (2001)
TBX1 is responsible for cardiovascular defects in velo-cardio-facial/DiGeorge syndrome. Cell 104:619-629.

Migaud M, Charlesworth P, Dempster M, Webster LC, Watabe AM, Makhinson M, He Y, Ramsay MF, Morris RG, Morrison JH, O’Dell TJ, Grant SG (1998) Enhanced long-term potentiation and impaired learning in mice with mutant postsynaptic density-95 protein. Nature 396:433-439.

Milner B, Squire LR, Kandel ER (1998) Cognitive neuroscience and the study of memory. Neuron 20:445-468.

Mintz IM, Sabatini BL, Regehr WG (1995) Calcium control of transmitter release at a cerebellar synapse. Neuron 15:675-688.

Mukai J, Dhilla A, Drew LJ, Stark KL, Cao L, MacDermott AB, Karayiorgou M, Gogos JA (2008) Palmitoylation-dependent neurodevelopmental deficits in a mouse model of $22 \mathrm{q} 11$ microdeletion. Nat Neurosci 11:1302-1310.

Murphy KC, Jones LA, Owen MJ (1999) High rates of schizophrenia in adults with velo-cardio-facial syndrome. Arch Gen Psychiatry 56:940-945.

Oskarsdóttir S, Vujic M, Fasth A (2004) Incidence and prevalence of the 22q11 deletion syndrome: a population-based study in western Sweden. Arch Dis Child 89:148-151.

Paterlini M, Zakharenko SS, Lai WS, Qin J, Zhang H, Mukai J, Westphal KG, Olivier B, Sulzer D, Pavlidis P, Siegelbaum SA, Karayiorgou M, Gogos JA (2005) Transcriptional and behavioral interaction between 22q11.2 orthologs modulates schizophrenia-related phenotypes in mice. Nat Neurosci 8:1586-1594.

Paylor R, Lindsay E (2006) Mouse models of 22q11 deletion syndrome. Biol Psychiatry 59:1172-1179.

Paylor R, McIlwain KL, McAninch R, Nellis A, Yuva-Paylor LA, Baldini A, Lindsay EA (2001) Mice deleted for the DiGeorge/velocardiofacial syndrome region show abnormal sensorimotor gating and learning and memory impairments. Hum Mol Genet 10:2645-2650.

Paylor R, Glaser B, Mupo A, Ataliotis P, Spencer C, Sobotka A, Sparks C, Choi CH, Oghalai J, Curran S, Murphy KC, Monks S, Williams N, O’Donovan MC, Owen MJ, Scambler PJ, Lindsay E (2006) Tbxl haploinsufficiency is linked to behavioral disorders in mice and humans: implications for 22q11 deletion syndrome. Proc Natl Acad Sci U S A 103:7729-7734.

Phillips RG, LeDoux JE (1992) Differential contribution of amygdala and hippocampus to cued and contextual fear conditioning. Behav Neurosci 106:274-285.

Prescott K, Ivins S, Hubank M, Lindsay E, Baldini A, Scambler P (2005) Microarray analysis of the Df1 mouse model of the 22q11 deletion syndrome. Hum Genet 116:486-496.

Puech A, Saint-Jore B, Funke B, Gilbert DJ, Sirotkin H, Copeland NG, Jenkins NA, Kucherlapati R, Morrow B, Skoultchi AI (1997) Comparative mapping of the human 22q11 chromosomal region and the orthologous region in mice reveals complex changes in gene organization. Proc Natl Acad Sci U S A 94:14608-14613.

Pulver AE, Nestadt G, Goldberg R, Shprintzen RJ, Lamacz M, Wolyniec PS, Morrow B, Karayiorgou M, Antonarakis SE, Housman D (1994) Psychotic illness in patients diagnosed with velo-cardio-facial syndrome and their relatives. J Nerv Ment Dis 182:476-478.

Ruiz-Perez VL, Carter SA, Healy E, Todd C, Rees JL, Steijlen PM, Carmichael AJ, Lewis HM, Hohl D, Itin P, Vahlquist A, Gobello T, Mazzanti C, Reggazini R, Nagy G, Munro CS, Strachan T (1999) ATP2A2 mutations in Darier's disease: variant cutaneous phenotypes are associated with missense mutations, but neuropsychiatric features are independent of mutation class. Hum Mol Genet 8:1621-1630.

Rutten K, Misner DL, Works M, Blokland A, Novak TJ, Santarelli L, Wallace TL (2008) Enhanced long-term potentiation and impaired learning in phosphodiesterase 4D-knockout (PDE4D) mice. Eur J Neurosci 28:625-632.

Stark KL, Xu B, Bagchi A, Lai WS, Liu H, Hsu R, Wan X, Pavlidis P, Mills AA, Karayiorgou M, Gogos JA (2008) Altered brain microRNA biogenesis contributes to phenotypic deficits in a 22q11-deletion mouse model. Nat Genet 40:751-760.

Swillen A, Vogels A, Devriendt K, Fryns JP (2000) Chromosome 22q11 deletion syndrome: update and review of the clinical features, cognitive-behavioral spectrum, and psychiatric complications. Am J Med Genet 97:128-135.

Uetani N, Kato K, Ogura H, Mizuno K, Kawano K, Mikoshiba K, Yakura H, Asano M, Iwakura Y (2000) Impaired learning with enhanced hippocampal long-term potentiation in PTPdelta-deficient mice. EMBO J 19:2775-2785.

Unni VK, Zakharenko SS, Zablow L, DeCostanzo AJ, Siegelbaum SA (2004) Calcium release from presynaptic ryanodine-sensitive stores is required 
for long-term depression at hippocampal CA3-CA3 pyramidal neuron synapses. J Neurosci 24:9612-9622.

Whitlock JR, Heynen AJ, Shuler MG, Bear MF (2006) Learning induces long-term potentiation in the hippocampus. Science 313:10931097.

Yan W, Jacobsen LK, Krasnewich DM, Guan XY, Lenane MC, Paul SP, Dalwadi HN, Zhang H, Long RT, Kumra S, Martin BM, Scambler PJ, Trent JM, Sidransky E, Ginns EI, Rapoport JL (1998) Chromosome 22q11.2 interstitial deletions among childhood-onset schizophrenics and "multidimensionally impaired." Am J Med Genet 81:41-43.

Yasuda R, Nimchinsky EA, Scheuss V, Pologruto TA, Oertner TG, Sabatini BL, Svoboda K (2004) Imaging calcium concentration dynamics in small neuronal compartments. Sci STKE 2004:15.
Zakharenko SS, Zablow L, Siegelbaum SA (2001) Visualization of changes in presynaptic function during long-term synaptic plasticity. Nat Neurosci 4:711-717.

Zakharenko SS, Zablow L, Siegelbaum SA (2002) Altered presynaptic vesicle release and cycling diring mGluR-dependent LTD. Neuron 35:10991110.

Zakharenko SS, Patterson SL, Dragatsis I, Zeitlin SO, Siegelbaum SA, Kandel ER, Morozov A (2003) Presynaptic BDNF required for a presynaptic but not postsynaptic component of LTP at hippocampal CA1-CA3 synapses. Neuron 39:975-990.

Zhang C, Wu B, Beglopoulos V, Wines-Samuelson M, Zhang D, Dragatsis I, Südhof TC, Shen J (2009) Presenilins are essential for regulating neurotransmitter release. Nature 460:632-636. 